\title{
Small bowel review: Part I
}

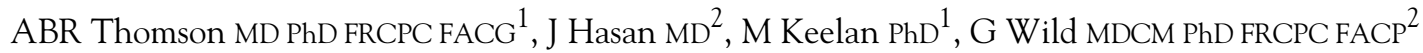

\begin{abstract}
ABR Thomson, J Hasan, M Keelan, G Wild. Small bowel review: Part I. Can J Gastroenterol 1998;12(7):487-504. In the past year there have been many advances in the area of small bowel physiology and pathology. In preparation for this review, over 500 papers were assessed, and some have been selected and reviewed, with a particular focus on presenting clinically useful information for the practising gastroenterologist.
\end{abstract}

Key Words: Acquired immune deficiency syndrome, Celiac disease Clostridium difficile, Human immunodeficiency virus, Small bowel

\section{Intestin grêle : tour d'horizon - partie I}

RÉSUMÉ : Au cours de l'année écoulée, nous avons franchi de grands pas dans le domaine de la physiologie et de la pathologie de l'intestin grêle. En vue de cette synthèse, plus de 500 articles ont été compilés. Certains ont été sélectionnés et passés en revue afin de présenter aux gastro-entérologues des renseignements qui leur seront utiles dans leur pratique.
$\mathrm{T}$ here have been many advances in the area of small bowel physiology and pathology. In part I of this review of the small bowel, over 500 papers were assessed, and some have been selected and reviewed, with a particular focus on presenting clinically useful information for the practising gastroenterologist.

\section{INFECTIONS}

Human immunodeficiency virus-1 infection and acquired immune deficiency syndrome-associated disease: The topic of acquired immune deficiency syndrome (AIDS) and intestinal disease has been reviewed (1). The gastrointestinal (GI) tract is involved in all stages of human immunodeficiency virus (HIV)-1 infection. HIV-associated diarrhea understandably diminishes the quality of life of the patient (2). Patients with AIDS, but not those who are HIV-infected, have increased intestinal permeability independent of whether diarrhea is present (3).

The GI and genitourinary mucosa are the surfaces through which HIV-1 is acquired in homosexual and heterosexual transmission, respectively. The GI mucosa participates in mother-to-child transmission as a consequence of the fetus' or infant's swallowing of HIV-1-infected amniotic fluid in utero, infected blood or cervical secretions intrapartum, or infected breast milk postpartum. After entry into the intestinal lamina propria, HIV-1 encounters an abundance of $\mathrm{CD}^{+}$lymphocytes and macrophages. Coreceptors participate with surface $\mathrm{CD}^{+}{ }^{+}$in facilitating the entry of HIV - 1 into cells $(4,5)$. Follicular dendritic cells present in lymph node follicles are capable of trapping the highly infectious HIV-1 and thereby provide a mechanism for continued infection in the presence of neutralizing antibody (6).

A diverse array of enteric pathogens is seen in patients with AIDS. Importantly, the natural history of these infections may be altered in the setting of HIV-associated disease. A variety of opportunistic and nonopportunistic pathogens may cause diarrhea in patients infected with HIV. Chronic diarrhea in patients with HIV infection is usually assessed by microbiological evaluation of a stool specimen. If no pathogen is identified, endoscopic examination of the upper and lower GI tracts is recommended, which usually increases diagnostic benefit, particularly in patients with weight loss and longer durations of diarrhea (7). Stool analysis yields the offending pathogen in only about half of HIV patients with diarrhea, but the use of rectal biopsy to diagnosis cytomegalovirus and adenovirus, and duodenal biopsy to search for ad-

\footnotetext{
${ }^{1}$ Nutrition and Metabolism Research Group, Division of Gastroenterology, Department of Medicine, University of Alberta, Edmonton, Alberta; ${ }^{2}$ Division of Gastroenterology and Department of Anatomy and Cell Biology, McGill University, Montreal, Quebec

Correspondence: Dr ABR Thomson, Department of Medicine, Division of Gastroenterology, University of Alberta, Edmonton, Alberta

T6G 2C2. Telephone 403-492-6490, fax 403-492-7964, e-mail alan.thomson@ualberta.ca

Received for publication April 15, 1998. Accepted July 8, 1998
} 
ditional pathogens, increases the identification of at least one potential pathogen in $80 \%$ of patients (8). Electron microscopy, impression smears and duodenal aspirate may yield extra information that may have a therapeutic implication. Thus, it is no longer tenable to simply perform a single stool culture in HIV patients with diarrhea; individuals with an identifiable bacterial pathogen should be treated specifically for that pathogen, and all other patients should receive symptomatic treatment with an antidiarrheal agent such as diphenoxylate.

Clinical learning point: If multiple stool cultures do not show a pathogen in the HIV-infected person with diarrhea, rectal and duodenal biopsies may help to establish a treatable diagnosis.

About $15 \%$ of HIV patients with diarrhea harbour Cryptosporidium species. The presence of Cryptosporidium species is generally detected by examination of stool specimens (using either a modified acid-fast stain or a monoclonal antibody-based immunofluorescent stain), or by direct visualization of hematoxylin and eosin stains of small bowel biopsy specimens. On the first stool specimen analysis, $96 \%$ of positive cases are detected, whereas $100 \%$ are detected by a second specimen analysis (9).

Clinical learning point: Multiple stool cultures may be needed to diagnose cryptosporidiosis in HIV -infected persons.

A cryptosporidiosis outbreak has been described in association with contamination of municipal drinking water. HIV-infected persons with CD4 counts of $50 / \mathrm{mm}^{3}$ or less are at increased risk of biliary symptoms and increased mortality within the year after infection (10).

HIV-infected patients with human cytomegalovirus infections (HCMV) may present with fever, diarrhea or weight loss, endoscopic or histological evidence of intestinal mucosal inflammation, and demonstration of the presence of HCMV in the mucosa or in the lamina propria. Amplification of HCMV-DNA by polymerase chain reaction may improve the detection of HCMV compared with the histological identification of intranuclear Cowdry's type A inclusions on biopsy specimens, or viral isolation by culture of the biopsy specimens. Quantification of HCMV-DNA in mucosal biopsies is useful for identifying the infection during maintenance therapy (11). Cytomegalovirus infection in renal transplant patients may produce subclinical involvement of the GI tract, as suggested by an increased intestinal permeability determined by the urinary lactulose to mannitol excretion ratio (12).

Villus architecture may be abnormal in approximately half of patients infected with HIV with or without chronic diarrhea, but the clinical significance of these mucosal abnormalities is uncertain (13). Other HIV-related mucosal structural changes include villus flattening, increased crypt depth and mononuclear cell infiltration.
Clinical learning point: An abnormal histological structure of a small bowel biopsy in an HIV-infected patient with diarrhea does not by itself point to a treatable cause of the symptom.

Microsporidia species are obligate spore-forming intracellular protozoal parasites that are a major cause of diarrhea and weight loss in patients with AIDS. Two species are recognized to cause diarrhea in HIV-seropositive individuals, with approximately $90 \%$ of cases caused by Enterocytozoon bieneusi, which may be treated with thalidomide, and a minority caused by Encephalitozoon intestinalis, which may respond to alblendazole (14).

Children with AIDS often suffer from growth retardation. In older children, weight and height decline in parallel. Loss of lean body mass may occur before a decrease in weight. These changes cannot be explained simply on the basis of inadequate nutrition (15). The weight loss that occurs in persons with HIV infection appears to be due to reduced energy intake (16).

Toxin-associated diarrhea: Enterotoxins are specialized bacterial proteins that bind to receptors on the enterocyte brush border membrane (BBM) and elicit intestinal fluid and electrolyte secretion. Clostridium difficile produces type A toxin, which induces fluid secretion, increases epithelial permeability and causes acute enteritis. In contrast, type B toxin has no effect on the mammalian intestine. The type $A$ toxin releases substance P (SP) from sensory afferent neurons, causes degranulation of mesenteric and mucosal mast cells and upregulates adhesion molecules on mesenteric venules. $\mathrm{SP}$ is an excitatory transmitter in smooth muscle, a putative excitatory neurotransmitter, a vasodilator and a mediator of inflammatory processes. The SP released from afferent neurons acts in the submucosal and myenteric plexuses. Indeed, SP may be the primary mediator of an axon reflex mediating neurogenic inflammation in the intestine (17). SP is a member of the tachykinin family of neuropeptides. Its actions are mediated via a heptahelical $G$ protein-coupled receptor known as the SP receptor (SPR) or neurokinin-1 receptor. SPR is immunoreactive along the length of the GI tract, with higher levels in the colon than in the ileum or stomach (18). After C difficile toxin A administration, more than $70 \%$ of enteric neurons show SPR endocytosis, whereas SPRs in control rats are largely confined to the plasma membrane.

A required first step for expression of enterotoxicity of $\mathrm{C}$ difficile toxin $\mathrm{A}$ in vivo is binding to enterocyte receptors on the luminal surface of the BBM. The rodent toxin A receptor contains a specific trisaccharide sequence. The product Synsorb 90 (SYNSORB Biotech Inc), an inert support carrying this trisaccharide, sequesters toxins on immobilized receptors in the intestinal lumen and inhibits the effect of toxin A on the ileal mucosa of rat ileum (19). Pretreatment with an SPR antagonist blocks both the inflammation and the pathological effects of $\mathrm{C}$ difficile toxin $\mathrm{A}$ in the rat intestine. $C$ difficile toxin $A$ in rat intestine increases the synthesis of nitric oxide and nitric oxide synthase (NOS). A NOS inhibitor augments, whereas a nitric oxide donor inhibits, 
toxin A-mediated ileal secretion and permeability when given before but not after $\mathrm{C}$ difficile toxin administration.

Clinical learning point: SP and its receptor may be involved in the damaging effects of the type A toxin of $\mathrm{C}$ difficile, and antagonists to the receptor or nitric oxide donors may be used therapeutically to block this toxinassociated secretion.

Results from scanning electron microscopy of the jejunal mucosa in children with chronic nonspecific diarrhea have demonstrated visible bacteria in $89 \%$ of specimens (20). This suggests that bacterial colonization of the surface of the small intestine is common in this setting. Escherichia coli serotype 0157:H7 may cause hemorrhagic colitis, which can be confused with ischemic colitis in elderly patients or in younger patients with Crohn's disease (21).

E coli heat-stable enterotoxins (ST) represent a family of homologous heat-stable peptide toxins that are elaborated by a variety of bacteria capable of causing enteric disease in humans (22). Many strains of enterotoxigenic $E$ coli produce ST, and the human intestine is hyperresponsive to the effects of ST during malnourishment and starvation. Guanylyl cyclase C (GCC) is a glycosylated receptor, predominantly synthesized by villus enterocytes that bind ST. During fasting, GCC is redistributed from the surface to the cytosol of enterocytes, which subsequently develop a sizable intracellular pool of immaturely glycosylated GCC (23). Maturation and recruitment of these intracellular receptors from the endoplasmic reticulum (ER) to the BBM may contribute to the hyperresponsiveness of the fasted gut to natural or bacterial GCC ligands. From a structural standpoint, crypt hyperplasia has been described in the small intestine during enteropathogenic E coli infection (24).

Colonization of the human small bowel with Vibrio cholerae results in massive secretory diarrhea, primarily through the action of the secreted enterotoxin cholera toxin. Cholera toxin binds to a glycosphingolipid receptor on the BBM $\left(\mathrm{G}_{\mathrm{m} 1}\right)$, with translocation of the A subunit across the membrane and reduction of the A subunit to form the enzymatically active $A_{1}$ peptide. This activates adenylate cyclase. Cholera toxin moves to its site of action on the basolateral membrane of the enterocyte by vesicular trafficking (25). Cholera toxin increases cAMP and decreases mucosal glutathione (GSH) concentrations, thereby inducing intestinal secretion (26). Cholera toxin produces intestinal secretion by activation of adenylate cyclase and release of 5-hydroxytryptamine (5-HT) from mucosal enterochromaffin-like cells, with no release of SP or mast cell discharge. Neither a NOS inhibitor nor a nitric oxide donor has any effect on cholera toxin-mediated secretion (27).

A cardinal feature of shigella virulence is the capacity of the organism to invade mammalian epithelial cells and elicit an intense inflammatory response. An initial phase of watery diarrhea may occur, and in mild cases this may be the only clinical presentation. There are two iron-regulated entero- toxins that alter electrolyte and water transport, and shigella enterotoxin 1 induces a time-and dose-dependent intestinal secretion in the rabbit animal model (28).

Listeria monocytogenes in milk may cause outbreaks of gastroenteritis and fever (29). The mechanism of these symptoms is unknown.

Lactobacillus species constitute an integral part of the healthy GI microecology and are involved in host metabolism. Adherence of Lactobacillus species strains has been studied in human intestinal cell lines (30). Bacterial therapy with Lactobacillus species is effective in patients with either ulcerative or pseudomembranous colitis. Administration of Lactobacillus species may also reduce the severity of methotrexate-associated enterocolitis in rats (31).

The nonpathogenic yeast Saccharomyces boulardii has been proposed for treatment of a variety of GI disorders associated with diarrhea. In a mouse model of rotavirus, treatment with $S$ boulardii had no effect on the infectionassociated changes in villus morphology or diarrhea, and specimens treated with $S$ boulardii contained yeast particles within the mucosal tissues (32).

Viral infections of the GI tract have also been reviewed (33).

Whipple's disease: Whipple's disease is a multisystem bacterial condition characterized by malabsorption and diarrhea, as well as by extraintestinal symptoms such as ocular manifestations including uveitis (34), polyarthritis and arthralgias (35). Diagnosis of Whipple's disease relies on the histological detection of sickleform particle-containing cells stained red by the periodic acid-Schiff reaction, with the diagnosis confirmed by electron microscopy. Whipple's disease is associated with infection by Tropheryma whippelii. $T$ whippelii may be detected in formalin- but not in Bouin-fixed small bowel biopsies (36). Polymerase chain reaction is a highly sensitive and specific test to amplify the sequences of bacterial $16 \mathrm{~S}$ ribosomal RNA in infected tissue from patients with Whipple's disease, to identify inconclusive and suspicious cases, and to monitor the response to therapy $(37,38)$.

\section{IMMUNOLOGY}

Basic concepts: The cellular elements that are central to the immunopathophysiology of a variety of intestinal diseases have been considered (39). The topic of cytokines and intestinal inflammation has been reviewed (40). Cytokines play an important role in the perpetuation and possibly the initiation of inflammation, through the relative balance of proinflammatory (interleukin [IL]-1, IL-6, interferon-gamma [IFN- $\gamma]$ and tumour necrosis factor-alpha [TNF- $\alpha]$ ) and anti-inflammatory (IL-4, IL-5, IL-10 and IL-13) cytokines. IL-10 is a cytokine secreted primarily by Thelper (TH) 2 subsets of CD4 ${ }^{+}$lymphocytes. IL-10 inhibits the synthesis of IFN $-\gamma$ and other proinflammatory cytokines expressed by TH1 clones. IL-10 enhances intestinal electroneutral sodium and chloride absorption (41). It has become increasingly apparent that epithelial cells play a key role in the immune response. For example, bacterial invasion of epithelial cells induces them to secrete IL-8 (42). 
T cells in the GI tract include the intraepithelial lymphocytes (IELs), lamina propria lymphocytes (LPLs) and peripheral blood lymphocytes. IELs are almost entirely $\mathrm{CD}^{+} \mathrm{T}$ cells, and the principal in vitro functions of IELs are cytolysis and IFN- $\gamma$ production. LPLs are phenotypically similar to peripheral blood lymphocytes but express markers of prior $\mathrm{T}$ cell activation such as CD45RO and the IL-2 receptor.

$\mathrm{T}$ cells also populate the interfollicular zone of Peyer's patches. Their predominant role is to assist in the differentiation of B cells towards immunoglobulin (Ig) A-producing cells and the generation of $\mathrm{T}$ suppressor cells responsible for the phenomenon of oral tolerance. Transforming growth factor-beta (TGF- $\beta$ ) is a critical regulatory cytokine in mucosal immunology. TGF- $\beta$ is produced by antigen-specific $T$ cells in Peyer's patches and is responsible for systemic suppression of orally administered antigens, ie, oral tolerance $(43,44)$.

The specialized antigen-transporting epithelial $\mathrm{M}$ cells in the follicle-associated epithelium overlying gut-associated lymphoid tissues (GALT) constitute the primary target for the oral delivery of vaccines. Binding of lectin is specific for the follicle-associated epithelium in the human ileum (45).

Malnutrition leads to a decrease in the capacity of $\mathrm{T}$ dependent cells to produce antibodies and to alter cellularmediated immunity as well as cytokine synthesis. Malnutrition during the suckling interval provokes alterations in B and $\mathrm{T}$ lymphocytes, and produces a lack of induction of the primary and secondary immune responses in the GALT. These changes reverse after three weeks of refeeding (46).

Leukocytes are transported between solid lymphoid organs and the periphery. Trafficking is mediated in an antigen-independent manner by a number of molecules present on endothelial cells and lymphocytes including selectins, integrins and tissue-specific addressins. Humans and rodents demonstrate major histocompatablity class II on the intestinal epithelium, but this is absent in pigs (47). Thus, it is important to choose the right species of animal as a surrogate of human tissue.

Techniques to isolate IELs have improved (48). Intraepithelial $\mathrm{T}$ lymphocytes in the small intestine consist of alpha-beta $T$ cell receptor (TCR)-bearing $T$ cells, as well as gamma-delta TCR-bearing T cells. Development and cytolytic activation of alpha-beta IEL are attenuated in germ-free mice fed a natural diet, but the number and cytotoxicity of gamma-delta IELs are comparable between conventional and natural diet-fed animals (49). IELs are an important source of biologically active molecules that modulate immune responses in the mucosa. TGF- $\beta$ enhances the effect of IL-1- $\alpha$ by increasing complement C3 synthesis in a rat, nontransformed, crypt-like intestinal epithelial cell line, IEC-6 (50). IELs increase enterocyte production of somatostatin, and removal of the $\mathrm{CD} 45^{+}$cell subset results in a reduction in somatostatin levels (51).

Human IELs are predominantly $\mathrm{T}$ cells of the $\mathrm{CD} 8{ }^{+} \mathrm{CD} 45 \mathrm{RO}^{+}$phenotype, and only a few are positive for the gamma-delta receptor. Gamma-delta IELs are present in patients with celiac disease or dermatitis herpetiformis and are also present in increased amounts in persons infected with HIV type 1 . That the median number of IELs and the percentage of gamma-delta IELs are different in HIVinfected patients from those in controls has not been confirmed, although the lamina propria CD4 cells are decreased and the CD8 cells are increased (52). Serum neopterin and beta-microglobulin are inversely related to duodenal gamma-delta IELs (53). These are found in Peyer's patches as well as in the epithelium and the lamina propria of the intestine, and have a chemotactic response to the alpha-chemokines, IL-8 and growth regulated oncogene. This response occurs by the binding of chemokines to common receptors (54). Five different chemokine receptors are known. Bacterial invasion induces epithelial cells to secrete IL-8 (42). IL-8 is a proinflammatory cytokine that is a chemoattractant for many cell types including $\mathrm{T}$ lymphocytes, natural killer cells and jejunal IELs. IL-8 is produced by intestinal epithelial cells after stimulation with cytokines such as IL-1 and TNF- $\alpha$. IL- 8 coordinates the inflammatory response to injury. Five different chemokine receptors have been described.

The cytokine IL-1- $\beta$, TNF- $\alpha$ and T cells are present in the intestinal muscular layers during inflammation, and these cytokines may modulate the activation of $\mathrm{T}$ cells (55). The cytokine response to vaccination may have a $\mathrm{T}$ helper cell type O-like profile (56). The gut is a cytokine-producing organ, and IL- 6 and TNF- $\alpha$ are released from Caco- 2 cells after $E$ coli challenge (57). Intracellular thiols modulate cellular functions; many cellular proteins require the presence of reduced thiol groups and oxidation of mixed disulphide formation with glutathione or cysteine.

Clinical learning point: The intestine produces a variety of pro- and anti-inflammatory cytokines that can be modulated to achieve desired therapeutic outcomes.

An important determinant of the rate of entry of lymphocytes into GALT is the adhesion of lymphocytes to endothelial cells. A variety of lymphocyte adhesion molecules such as selectins and integrins play a role in the organ-specific homing of lymphocytes. The alpha 4 -integrins mediate lymphocyte homing to the gut mucosa via a receptor-ligand interaction. At sites of inflammation, leukocytes become attached to the vessel wall via a rolling interaction mediated by selectin molecules. Then, the leukocytes adhere at a single location on the vessel wall before diapedesis occurs. In Peyer's patches, $\mathrm{T}$ lymphocytes selectively adhere to postcapillary venules. The enhanced rolling and adherence of lymphocytes observed in Peyer's patches and submucosal venules of villi of lipopolysaccharide-treated rats are preceded by a reduction in sheer rate. These actions are mediated by alpha $_{4}$-integrins and partly by beta 2 -integrins (58).

Intestinal transplantation: The approach to patients requiring small intestinal transplantation is evolving (59). The early histopathology of acute small intestinal rejection has been described in animals (60) and in humans (61). Rejection, infection and graft-versus-host disease are major obstacles to successful clinical application of small bowel 
transplantation. Acute graft rejection is characterized by a combination of crypt injury, mucosal infiltration by mononuclear cells and increased crypt cell apoptosis. This occurs in a patchy manner, is often localized in the ileum and may progress to mucosal ulceration. There appears to be no immunological difference between jejunal and ileal grafts, and an equal dose of cyclosporine (CyA) does not alter the course of rejection of either jejunal or ileal grafts (62). Following small bowel transplantation, physiological lymphocyte migration leads to repopulation of the graft with host cells, even in the absence of acute rejection (63). Rejection of small bowel allografts is accompanied by graft infiltration by host cells, and the gamma-delta TCRs play a role in local regulation of graft rejection (64).

Clinical learning point: Rejection, infection or graftversus-host disease may limit the clinical benefit of small bowel transplantation in some persons.

Bacterial lipopolysaccharide may result in endotoxininduced disseminated intravascular coagulation or shock. Endothelin (ET) is a potent endothelium-derived contracting factor, resulting in long lasting vasoconstriction. After endotoxin treatment, calcium-dependent NOS activity decreases, and platelet-activating factor and ET concentrations increase (65). Induction of nitric oxide generation, as demonstrated by spin trapping of nitric oxide, begins early in the small intestine following the induction of endotoxemia and continues later in the liver, kidney and plasma (66).

Intestinal bacterial translocation can be defined as the passage of bacteria and bacterial products from the intestinal lumen to otherwise sterile extraintestinal sites (67). Infections represent the primary cause of graft failure, and the presence of the colon in the transplanted graft increases the risk of severe infections $(68,69)$. Septic episodes are probably related to bacterial translocation, but antibiotic luminal flushing does not appear to have a protective effect, at least in a dog model (70).

The second most frequent complication in patients with small bowel transplantation is rejection. This is usually diagnosed histologically, although the finding of intestinal fatty acid binding protein (I-FABP) released into the peripheral circulation may prove to be diagnostically useful (71). The serum levels of I-FABP may also be elevated with mesenteric infarction in a nontransplanted setting (72).

Clinical learning point: The finding of I-FABP in the peripheral blood of a person with a small bowel transplantation may suggest graft rejection.

Small bowel transplantation necessitates extrinsic denervation, with disruption of enteric neural continuity and lymphatic drainage, ischemia-reperfusion $(\mathrm{I} / \mathrm{R})$ injury and immune effects. Absorption and motility of the bowel are altered (73). This intestinal dysmotility is augmented in prolonged preservation grafts compared with those with brief preservation (74). Some macrolides such as erythromycin have been proposed as GI prokinetics because of their ability to stimulate gut motility through the activation of motilin receptors. FK506 is a macrolide and stimulates small bowel motility in the pig in vivo (75). FK506 also may prevent the development of ischemia in the intestinal allograft during acute cellular rejection (76).

Clinical learning point: FK506 may stimulate the altered motility in the transplanted small bowel and may prevent the development of ischemia in the allograft during acute cellular rejection.

Nutritional maintenance may be a clinical problem following small intestinal transplantation in humans. Carrier-mediated nutrient transport decreases in a canine jejunal autotransplantation model (77). Following small intestinal transplantation, lymphatic absorption of lipids via the mesenteric duct is reduced, but there is higher jugular vein fat recovery, with preservation of the overall normal level of dietary fat absorption (78). After stopping immunosuppression following small intestinal transplantation, fecal lipid excretion increases during the rejection process (79).

The antihypertensive drug diltiazem reduces the incidence of both CyA nephrotoxicity and graft rejection. Both CyA and diltiazem are metabolized by the cytochrome $\mathrm{P} 450$ enzyme, and diltiazam is a competitive inhibitor of CyA metabolism in the liver. The absorption of CyA is highly variable. Secretion of $\mathrm{CyA}$ in the kidney is modulated by P glycoprotein, a member of the ATP-dependent multidrug export pump family. Changes in $\mathrm{P}$ glycoprotein expression may alter multidrug resistance by reducing the intracellular accumulation of anticancer drugs by pumping them out of cells. $\mathrm{P}$ glycoprotein is localized on the luminal membrane of intestinal epithelial cells, and transports certain drugs and some peptides. It plays an important role in the barrier function of the intestine by transporting some substances out of the intestine cell back into the lumen (80).

Clinical learning point: Absorption of $\mathrm{Cy} A$ is highly variable; this may be due in part to the varying activities of $\mathrm{P}$ glycoprotein pumping CyA out of the enterocytes.

\section{BLOOD FLOW AND INTESTINAL ISCHEMIA}

The mucosal lining of the intestine is one of the most highly perfused tissues of the body, receiving up to $80 \%$ of total intestinal blood flow under resting conditions. Mesenteric feed arteries as well as microcirculatory vessels are true resistance vessels, and both participate in the control of intestinal blood flow. About one-third of the vascular flow resistance in the intestinal feed arteries and about one-half of the vascular proresistance within the microcirculation of the intestinal wall occurs in these vessels. Regulation of mucosal blood flow occurs at the level of the submucosal arteriole, the final resistance vessel of the mesenteric circulation. Reflux vasodilation involves both intrinsic (enteric) and extrinsic (sensory) neural pathways. Both vasodilator pathways can be activated independently by mucosal stimulation, and 
both have afferent and efferent components confined to the mucosal and submucosal neuronal plexuses. Neurogenic vasodilation of submucosal arterioles results from the release of acetylcholine and/or neuropeptides from the intrinsic submucosal neurons, as well as the release of SP and calcitonin gene-related peptide from extrinsic sensory nerves (81).

Neutrophils accumulate in the small blood vessels during ischemia, as well as after reperfusion. Neutrophils adhere to the endothelium, invade tissues and mediate cell injury. Injury is caused in part by the plugging of the small vessels, as well as by the release of cytotoxic substances such as reactive oxygen, proteases, cationic proteins and collagenase. Cytokine-induced neutrophil chemoattractant is a member of the IL-8 family, and plasma IL-8 levels are elevated during $\mathrm{I} / \mathrm{R}$ injury in the rat. These elevations in IL- 8 are correlated with the duration of ischemia and with the degree of mucosal damage (82).

The production of IL-1 is enhanced in the intestinal mucosa during endotoxin infusion (83). Splanchnic ischemia and gut barrier failure play important roles in the development of sepsis, as well as in the maintenance of the systemic inflammatory response that leads to the multiple organ failure syndrome (84). In a rat model of necrotizing enterocolitis, ET-1 plays a role in the microcirculatory disturbance, with leukocyte sticking and decreased red blood cell velocity. These abnormalities may be mediated by $\mathrm{ET}_{\mathrm{A}}$ receptors, which are closely related to the increased production of platelet activating factor and to the decreased synthesis of constitutive nitric oxide (65). Nitric oxide is an important differential regulator of vascular tone in the developing GI circulation (85).

The metabolic process has profound effects on the regulation of intestinal microvascular function, with blood flow falling when sodium absorption is suppressed by isosmotic replacement of luminal sodium chloride with mannitol. This decline in blood flow may be through the suppression of nitric oxide-dependent processes (86).

Pretreatment of rats with $\mathrm{L}$-arginine ameliorates survival after intestinal $\mathrm{I} / \mathrm{R}$ injury in rats and improves mucosal barrier function (87). I/R is mediated by the production or release of reactive oxygen-derived free radicals when hypoxic tissues are reoxygenated during reperfusion. $\mathrm{I} / \mathrm{R}$ injury may be reduced by the administration of free radical scavengers, inhibition of xanthine oxidase by neutrophil depletion, inhibition of leukocyte endothelial adherence or the administration of platelet activating factor in rats. L-arginine accelerates the recovery of intestinal morphology and hydrolase activities after ischemic insult. This implicates nitric oxide in the recovery of the intestinal mucosa after ischemic injury. Nitric oxide activates guanylate cyclase and increases cGMP formation. ATP-magnesium chloride prevents the increase of ${ }^{51} \mathrm{Cr}$-EDTA permeability during ischemia, without alterations in tissue ATP levels or increases in intestinal blood flow (88).

The mesenteric feed arteries are important for the regulation of vascular resistance. Regional blood flow and resistance arteries are constricted by neurohumoral factors such as noradrenaline and angiotensin II, with vascular resistance increasing and regional blood flow decreasing. Conduit arteries represent a low resistant system, which provides a buffering function, translating phasic flow of cardiac output to a continuous flow at the peripheral level. ET-1 and ET-derived peptide induce potent vasoconstriction in the resistance vessels compared with the conduit portion of isolated human mesenteric arteries (89).

Administration of the opiate receptor blocker naloxone ameliorates circulatory shock during endotoxemia, intestinal I/R and hypovolemia. Intestinal metenkephalin-like immunoreactivity release and sympathetic activation occur only after an ischemic insult of sufficient magnitude to cause circulatory collapse. This suggests an 'on-off' rather than a 'dose-response' pattern. With reperfusion, there is a correlation between the release of intestinal metenkephalin-like immunoreactivity and noradrenaline (90).

Prolonged oxygen deficiency induces the loss of intestinal metabolic integrity that is associated with altered peroxide detoxication activity and mitochondrial respiratory function (91). Complement may play a crucial role in systemic shock induced by intestinal ischemia (92).

Ischemic tissue damage is associated with free radical formation. Following intestinal ischemia there is a rapid and transitory induction of all immediate early gene mRNAs (such as c-fos, c-jun and zif/268). These gene mRNAs return to basal levels $3 \mathrm{~h}$ after recirculation. In contrast, expression of both ornithine decarboxylase (ODC) and the regulatory protein antizyme of ODC mRNAs initially decreases and then increases after recirculation (93).

Subtle events occur during the ischemic cold preservation of small bowel that 'prime' the graft for subsequent reperfusion injury. There is a time-dependent appearance of phospholipase A2 activity in the preservation media of ischemic rat intestinal grafts. This may lead to the breakdown of membrane phospholipid to release detergent products such as arachadonic acid and lyso derivatives (94). Mucosal permeability increases following acute $I / R$, and administration of prostaglandin E suppresses these changes by stimulating ATP and cAMP synthesis. $\mathrm{PGE}_{1}$ may, therefore, protect against acute $\mathrm{I} / \mathrm{R}$ injury in the small intestine (95).

Clinical learning point: Ischemic damage to the intestine is associated with free radical formation, and nitric oxide and prostaglandins may repair damage after ischemic injury.

Blood flow is often measured by the dye dilution method. Ultrasonic transit time flowmetry is an alternative method for quantifying intestinal blood flow in fed and in endotoxemic animals. Doppler ultrasound, a noninvasive technique providing assessment of splanchnic hemodynamics (splanchnic arteriole inflow in the superior mesenteric artery and splanchnic venus outflow in the portal system), is useful for demonstrating alterations in intestinal blood flow in patients with inflammatory bowel disease (96). Pulsed Doppler flowmetry may be useful for detecting an increase in blood 
flow in the superior mesenteric artery during indomethacininduced intestinal injury and inflammation (97).

Clinical learning point: Doppler flowmetry may be useful for detecting changes in blood flow in the injured intestine.

Patients with ischemic bowel disease have elevated serum levels of I-FABP, and this characteristic may serve as a useful biochemical marker for the diagnosis of mesenteric infarction (72). Computed tomography scans used for the diagnosis of intestinal ischemia have a sensitivity of $100 \%$ but unfortunately have a specificity of only $61 \%$ (98). Computed tomography scans are useful in distinguishing intestinal obstruction from paralytic ileus, as well as in establishing the cause of the obstruction, and the presence or absence of strangulation (99). For the diagnosis of acute mesenteric ischemia, the findings include arteriole or venus thrombosis, intramural gas, portal venous gas, focal lack of bowel wall enhancement, and liver or splenic infarcts (100). Duplex and colour Doppler flow ultrasound are also useful for differentiating between ischemic and inflammatory bowel wall thickening (101). Intestinal hypoxia delays small intestinal transit in vivo (102).

Mesenteric venous thrombosis may be secondary to infection (such as appendicitis or pelvic abscess) or to hematological conditions (polycythemia and the postsplenectomy state). Acquired hypercoagulability may be related to a deficiency of an anticoagulation factor such as protein $\mathrm{C}$ or protein S, or to an antithrombin deficiency (103).

\section{SALT AND WATER ABSORPTION, AND DIARRHEA}

Sodium/hydrogen exchanger (NHE) activity is essential for intracellular $\mathrm{pH}$ homeostasis, transepithelial ion and water transport, cell volume regulation, and cell proliferation and adhesion. There may be as many as six NHEs in this multigene family, sharing a $40 \%$ to $60 \%$ amino acid identity, with similar plasma membrane topologies. The activity of NHEs is modulated by a variety of molecular signals including neurotransmitters, growth factors, peptide hormones, chemotactic factors, lectins and osmotic shrinkage. Many of these stimuli transmit their signals via interactions with plasma membrane receptors that are coupled with a diverse family of heterotrimeric (alpha-beta-gamma) GTP-binding proteins ( $G$ proteins). Receptor-mediated activation of $G$ proteins leads to the dissociation of alpha-GTP from the beta-gamma subunits. The alpha- or beta-gamma subunits bind and regulate a variety of effector molecules. Activation of the G protein modulates the production of various second messengers, such as cAMP, cGMP, diacylglycerol, inositol trisphosphase and calcium.

The NHEs have a similar hydropathy profile, predominantly the transmembrane $\mathrm{N}$ terminus, and a more hydrophilic cytoplasmic C terminus. NHE1 is the 'housekeeping' exchanger isoform that is present in nearly all mammalian cells. NHE1 is stimulated by volume increases that duplicate the 'physiological' volume changes that occur when these cells absorb sodium-cotransportive solutes (104). The modest $5 \%$ to $7 \%$ volume increase in jejunal villus epithelial cells that occurs during absorption of sodium and solute activates potassium and chlorine channels; the resulting potassium chloride efflux returns the cell volume to normal.

NHE3 is present in the BBM of enterocytes, and the activity of NHE3 is inhibited by forskolin (which directly stimulates adenylate cyclase) (105). NHE1 is present uniformly throughout the length of the human intestine, but the mRNA levels for NHE2 and NHE3 are higher in the ileum and jejunum than in the colon. NHE2 and NHE3 play a role in the transcellular sodium absorption by dual ionexchange mechanisms involving coupling of the NHE and the chloride/bicarbonate exchanger (106). NHE may be a major mediator of postprandial sodium and water absorption in the ileum (107). Chronic inflammation inhibits chloride/bicarbonate exchange in villus cells, and sodium/hydrogen exchange in crypt cells may be stimulated by inflammation (108).

Clinical learning point: The various NHEs play a role in the absorption of salt and water, as well as a variety of other physiological functions in the intestine.

Activation of protein kinase $\mathrm{C}$ and cAMP-dependent protein kinase stimulates transport by NHE-1 and NHE-2 but depresses transport by NHE-3. This suggests that the isoforms are differentially responsive to agonists of the protein kinase A and protein kinase C pathways (109). Separate regions of the $\mathrm{C}$ terminus of NHE3 are involved with stimulation or inhibition of sodium/hydrogen exchange activity, with both stimulatory and inhibitory domains having several distinct subdomains (110). NHE-1 is a calmodulin-binding protein containing high and low affinity calmodulin-binding sites. There is a functional interaction of the autoinhibitory domain of NHE-1 with the hydrogen-modifier site of a different isoform, NHE-3 (111).

Functional coupling of the chloride/bicarbonate and NHE exchangers is observed in villus enterocytes. This favours sodium chloride absorption, whereas chloride/bicarbonate exchange in the crypt cell provides a possible mechanism for bicarbonate ion secretion. At least three classes of sodium-independent chloride/bicarbonate exchangers (designated anion exchanger [AE] 1, AE2 and AE3) have been identified in the AE gene family. AE2 is the most likely candidate for the chloride/bicarbonate exchanger in the BBM of enterocytes. AE2 mRNA does not vary along the cryptvillus axis, but the AE2 mRNA falls during the transition between the suckling and weanling stages in rats. Thyroxine administration decreases AE2 mRNA, and dexamethasone has no effect (112). The sodium:potassium:2chlorine cotransporter has a polarized distribution in intestinal epithelium and may be associated with other membrane proteins (113).

Epidermal growth factor (EGF) increases sodium chloride absorption, acting via basolateral membrane receptors. 
Phosphatidylinositol 3-kinase (PI 3-kinase) is an enzyme in the intracellular signalling pathways and is an intermediate in EGF stimulation of intestinal sodium absorption by way of the NHE (114). PI 3-kinase forms a complex with the growth factor receptor and with oncogene products. PI 3 kinase is implicated in the growth signalling mechanism of receptors and oncogenes that act through tyrosine kinases.

5-HT mediates cholera toxin-induced secretion (115). The secretory response to 5 -HT is mediated via the enteric nervous system (116). 5-HT-induced secretion is a consequence of the inhibition of neutral sodium chloride absorption, together with stimulation of chloride ions or bicarbonate secretion. This process is electrogenic and may be the cause of a direct action of 5-HT on transporting cells, or may be the result of an increase in cytosolic calcium levels and hypopolarization of the intestine. 5-HT acts mostly on 5-HT3 or 5-HT3-like receptors, and enhances the sensitivity of visceral neurons projecting between the gut and the central nervous system (117).

Cystic fibrosis (CF) is an autosomal recessive disorder caused by mutations in the $\mathrm{CF}$ transmembrane conductance regulator (CFTR) gene. The GI manifestations of CF have been reviewed (118). In vivo, chloride and water secretion is reduced in patients with CF (119). The CFTR gene encodes an epithelial cAMP-activated chloride channel. Normally, neurohumoral agents such as vasoactive intestinal peptide (VIP) and carbachol (a muscarinic agonist) initiate fluid secretion in the intestinal crypt compartment. A subpopulation of villus cells with high levels of intracellular CFTR expression exists in the proximal small intestine (120). The defective cAMP-activated chloride channel and the cell volume regulation after hypotonic challenge are both defective in intestinal crypt epithelial cells isolated from CFTR $-/-$ mutant mice. This leads to an inability of the potassium conductance to provide a pathway for the exit of this cation during volume adjustments (121). A cAMP-activated epithelial basolateral membrane chloride conductance regulator has been cloned. This shows 49\% identity with multidrug resistance-associated protein (P-gp) and 29\% identity with CFTR (122).

Clinical learning point: $\mathrm{CF}$ is an autosomal recessive disorder caused by mutations in the CFTR gene.

Opioid peptides promote intestinal absorption by stimulating sodium chloride absorption and by inhibiting chloride secretion. This process is mediated by submucosal neurons, although both the mu- and delta-types of opioid receptors are present in the crypt epithelium of guinea-pigs, and may contribute to opioid-mediated regulation of intestinal secretion (123).

VIP is the pathophysiological mediator of several small intestinal hypersecretory states. VIP binds to mucosal receptors and increases intracellular cAMP. The somatostatin analogue octreotide inhibits intestinal motility and secretion, and is useful in the management of persons with persistent diarrhea associated with neuroendocrine tumours (par- ticularly VIPoma and carcinoid tumours), congenital microvillus atrophy, short bowel syndrome, dumping syndrome, secretory diarrhea associated with radiotherapy or chemotherapy, and possibly with AIDS-related diarrhea (124). To avoid hypoglycemia in patients with diabetes mellitus-associated secretory diarrhea treated with octreotide, a low initial dose should be used. A more aggressive approach to the selection of the initial octreotide dose can be used for the treatment of the other somatostatin-responsive disorders (125).

Clinical learning point: Octreotide may be useful in the treatment of selected patients with secretory diarrhea.

Peptide YY (PYY), produced by endocrine L cells of the distal intestine, is released during meals. PYY induces many inhibitory effects on GI secretion and motility. High affinity PYY receptors on rat enterocytes have been implicated in the inhibition of cAMP production. PYY in high doses inhibits $\mathrm{PGE}_{2}$-induced secretion in healthy humans (126). PYY decreases VIP-mediated secretion by way of specific Y4 mucosal receptors (127).

Neuropeptide Y (NPY) is an inhibitory peptide and a regulator of the antigen-induced intestinal secretory response, acting on epithelial and/or neural sites. NPY reduces the secretory responses of sensitized rat jejunum to antigen challenge, probably because NPY acts at both epithelial and neural sites (128). SP reverses the inhibitory action of NPY evoked by luminal antigens.

Nitric oxide is an important mediator of neural, cardiovascular and GI functions. Nitric oxide is derived from L-arginine by the action of the stereospecific enzyme NOS. NOS is present in the myenteric plexus, submucosal arterioles and venules, as well as in enterocytes (129); NOS may be present in enterocytes, but this is controversial. Unlike other amino acids, L-arginine induces water secretion, probably by acting as a precursor of the free radical.

Antidiarrheal therapy has been reviewed (130). Oral rehydration solutions (ORS) containing glucose and sodium are widely used in the treatment of patients with diarrhea. Glucose stimulates water and sodium chloride absorption. Glucose absorption removes solute from luminal fluid, making the luminal fluid hypotonic to submucosal fluid and thereby promoting water absorption. Increased water flow via the paracellular pathway entrains sodium and chloride ions, and passively promotes absorption of sodium chloride. Approximately two-thirds of the glucose-stimulated sodium absorption is by solvent drag, and the remaining one-third is the result of cotransport of sodium with glucose. With cholera toxin, the contribution of solvent drag declines, but the contribution of cotransport doubles (131).

An inhibitor of endotoxin reduces electrogenic chloride movement in a sepsis-induced model of intestinal secretion (132). ORS containing rice flour reduce stool output in children with acute diarrhea more effectively than rice-dextrin (133). Reduced-osmolarity ORS in children with acute noncholera diarrhea living in developing countries have benefi- 
cial effects on the clinical course (134). The active fraction in rice that is beneficial for the treatment of acute diarrhea in ORS has a low molecular weight, is hydrophobic and is neither a peptide nor a glycoprotein (135). Glutamine, a nonessential amino acid, provides a major energy source for the intestinal epithelium, stimulates sodium absorption and may be a useful component in ORS (136).

In Egyptian children with acute diarrhea, reduced-osmolarity ORS ( $75 \mathrm{mmol} / \mathrm{L}$ of sodium and glucose each) diminish stool output in a portion of children with vomiting during the rehydration phase and reduce the need for supplemental intravenous therapy compared with the standard World Health Organization ORS (osmolality $311 \mathrm{mmol} / \mathrm{L}$ ) (137).

Clinical learning point: ORS, with a reduced osmolarity or made with rice flour, are clinically useful for treating children with acute diarrhea.

Glycerol is a hydrophilic, absorbable, energy-rich solute that can be added to a high energy beverage containing corn syrup to improve the intestinal absorption of tap water. This is more effective then preparations on the market containing sucrose and glucose-fructose syrups.

Although dehydration and hyponatremia are controlled by ORS therapy, disease duration and stool frequency remain unchanged. Carboxymethylcellulose may improve ORS effectiveness, doubling the absorption of sodium, potassium and water in a rat model of chronic osmotic-secretory diarrhea (138).

The sympathetic nervous system exerts tonic control on intestinal fluid transport, and this effect is mainly through peripheral alpha 2 -adrenoceptors (139). Alphaz-adrenoceptor agonists inhibit intestinal motility and promote the absorption of fluid from the lumen of the intestine. Alphazadrenoceptor agonists inhibit intestinal fluid secretion produced by prostaglandin, VIP and cholera toxin. The enterocytes of the small intestinal epithelium are innervated by adrenergic neurons, and there are four distinct subtypes of alphaz-adrenoceptors.

\section{CELIAC DISEASE}

Pathogenesis: There is mounting evidence that T lymphocytes are central to the development of gluten-sensitive enteropathy or celiac disease. Gliadin-sensitive T lymphocytes are important in the immune pathogenesis of celiac disease, and the secretion of IFN- $\gamma$ may lead to enterocyte damage (140). Also, the production of cytokines by inflammatory cells (especially $\mathrm{T}$ cells and macrophages) is likely responsible for the histological changes in celiac disease. T lymphocytes can be defined according to the profile of cytokines that they secrete. The Th1 response is predominately that of IFN $-\gamma$ and IL-2, and drives cell-mediated responses. The Th2 cytokines (including IL-4 and IL-10) control antibodymediated processes. In celiac disease there is a Th1 response, with increased concentrations of IL-2 and IFN- $\gamma$, as well as IL- 6 and TNF- $\alpha$.
Patients with celiac disease have no primary deficiency of IL-4- or IL-10-producing cells (141). Four hours after challenge with gliadin, the lamina propria of the intestine of patients with celiac disease contains increased numbers of cytokine mRNA-expressing cells (142). Peptide A (corresponding to amino acids 31-49 of A-gliadin) is toxic in vitro to the jejunal mucosa of both treated and untreated celiac disease patients (143). IELs isolated from gliadin-treated rats transfer mucosal damage; this raises the possibility that gluten-induced enteropathy has an autoimmune component (144). Gluten-reactive proliferative blood T cell clones obtained from peripheral blood secrete cytokines. IFN- $\gamma$ is the major cytokine product, with lesser amounts of IL-4, IL-5, IL-6, IL-10, TNF and TGF- $\beta$ (145).

Clinical learning point: Cytokines play a role in the histological damage produced by gluten in persons with celiac disease.

IELs are cytotoxic $T$ cells that are in a resting state in the normal small bowel but are activated in patients with celiac disease (146). Signs of activated T cell-mediated mucosal immune response can be detected in the small bowel of patients with celiac disease. All patients with celiac disease have an increment in the absolute number of IELs in the rectal mucosa after rectal gluten challenge, and half of these young patient's siblings also react to rectal instillation of gluten (147). IELs constitute an unusual immunological compartment with a heterogenous population of cells. Most of them bear the CD8 phenotype consisting of two ontogenically different populations: one bears the CD8 molecules made of two different polypeptide chains (alpha and beta chains) and the other bears CD8 molecules lacking beta chains (heterodimeric alpha/beta $\mathrm{CD} 8^{+}$and homodimeric alpha $C D 8^{+}$) (148). Within hours of an in vivo gluten challenge, there is an acute inflammatory response in the jejunal mucosa, with complement utilization and ultrastructural vascular changes. This is followed by recruitment of $T$ lymphocytes in the mucosa with an increase in IEL, crypt hyperplasia and villus atrophy. Gliadin challenge may initiate two parallel pathways - one leads to $T$ cell activation, and the other precedes it (149). T lymphocytes that migrate in the higher lamina propria compartments are mainly $\mathrm{CD}^{+}$cells and show markers of activation; migrating IEL or $\mathrm{CD} 8^{+}$do not express these markers.

Celiac disease shows a strong human leukocyte antigen (HLA) association, predominantly with a DQ heterodimer (DQ2 and to a lesser extent DQ8). Gluten-specific mucosal $\mathrm{CD}^{+} \mathrm{T}$ cells (implying the alpha/beta TCR) are central in the immunopathology of this disease. Isolation of gliadinspecific HLA-DQ2-restricted T lymphocyte clones from the intestinal mucosa of patients with celiac disease supports a role for cell-mediated immunity in the pathogenesis of this condition. T cell clones from the small intestinal mucosal of patients with celiac disease are restricted by the celiac disease-associated HLA-DQ2 and HLA-DQ8 molecules. 
The small intestinal, gliadin-specific $\mathrm{T}$ cells from patients with celiac disease showed diverse reactivity patterns (150).

The 'flat mucosa' in celiac disease is associated with increased numbers of proliferating crypt cells. The flat mucosal surface is not due to excess 'exfoliation' but is due to an increase in enterocyte programmed cell death (apoptosis) (151). This implies the possibility of a link between proliferation and apoptosis; an antiapoptosis agent may be of some use clinically. Rates of epithelial cell renewal in celiac disease are increased sixfold, and this is associated with increased rates of mucosal protein synthesis (152).

Clinical learning point: The flat mucosa in patients with celiac disease is due to increased apoptosis (programmed cell death) and not to enhanced exfoliation, as was previously thought.

Indirect measures of diagnosis - Serology: Screening tests for celiac disease have been reviewed (153). The IgA class antiendomysium antibodies (EMA) are powerful serologic markers of untreated celiac disease, with 100\% specificity and greater than $90 \%$ sensitivity in adults. Both EMA and antigliadin antibodies (AGA) show high positive but low negative predictive values of intestinal histological outcome. Thus, neither serologic markers nor dietary inquiries should be regarded as reliable predictors of the return of the intestinal histology to normal (154).

In patients with suspected celiac disease, IgA-EMA is present in about $4 \%$ of control subjects, whereas IgA gliadin antibodies (IgA-AGA) are present in 15\% and IgG-AGA in 34\% (155). AGA, but not EMA, sensitivity decreases with age. The mucosa is found on biopsy to be flat in $99 \%$ of persons in whom EMA and AGA are both present in the serum. If both EMA and AGA are negative, the mucosa is histologically normal in $99 \%$. In first degree relatives of patients with celiac disease, the positive predicted value of EMA is $91 \%$, that of IgA-AGA is $74 \%$ and that of IgG-AGA is $45 \%$. Thus, EMA screening is a good test for the diagnosis and follow-up of persons with celiac disease and is useful for the identification of its silent and latent forms. Neither gliadin antibodies nor increased intensity of IEL is an obligate marker of latent celiac disease, and EMAs are likely to be the best predictors of evolution towards villus atrophy (156). Because of the high cost of monkey esophagus for the preparation of material for the EMA tests, human umbilical cord tissue has been developed as a source of EMA and has been shown to be sensitive for large scale screening for celiac disease (157).

Clinical learning point: Measurement of IgA-EAM antibodies is sufficiently sensitive to recommend its use in screening symptomatic persons for possible celiac disease.

Routine use of IgA human umbilical cord EMA increases the diagnosis of celiac disease to $15 \%$ above that obtained by measuring IgA and IgG-AGA. EMA and AGA have been used in large scale screening programs involving 5280 stu- dents aged 11 to 15 years. The prevalence of previously undiagnosed celiac disease was 4.36/1000 in the screened subjects and 5.03/1000 in the general population, with a ratio of previously known to undiagnosed cases of 1 to 6.4 (158).

Clinical learning point: Celiac disease may be as prevalent as five/1000 asymptomatic young persons. Data for Canada are not available.

AGAs have been identified in $57 \%$ of 53 patients with neurological dysfunction of unknown cause despite full investigation (for example, ataxia, peripheral neuropathy or mononeuritis multiplex). This raises the possibility that gluten sensitivity may have an etiological significance in these conditions (159). Distal duodenal biopsies performed in 26 of 30 AGA-positive patients with undiagnosed neurological illness revealed histological evidence of celiac disease in $35 \%$ and nonspecific duodenitis in $38 \%$ of persons. It is unclear whether a gluten-free diet in these persons improves the associated neurological condition.

Clinical learning point: A variety of neurological disorders may occur in patients with known or previously unsuspected celiac disease.

For unknown reasons, the prevalence of celiac disease is increased more than 100 -fold in persons with Down's syndrome (160).

Permeability: Permeation of the intestine to larger probes such as lactulose increases, and permeation of small monosaccharides such as mannitol decreases, in celiac disease patients. An increased urinary lactulose to mannitol excretion ratio is common in persons with celiac disease, although some workers have found the lactulose to mannitol ratio to be abnormal in less than two-thirds of such individuals (161). This suggests that the sugar intestinal permeability test may have a limited role in diagnosing celiac disease, particularly in individuals who have no symptoms. However, increased sucrose permeability may be a sensitive marker for advanced celiac disease (162). The prevalence of small intestinal permeability to mannitol and to lactulose may be higher in Indians and Afro-Caribbeans residing in the United Kingdom (163). The site of permeability changes can be established by defining concentration/time profiles in the serum of a series of simultaneously ingested indicators with a well defined known absorption site (164).

Clinical learning point: Intestinal permeability measurements are not sufficiently sensitive to select symptomatic patients for a small bowel biopsy to diagnose celiac disease.

Measurements of the effective thickness of the intestinal unstirred water layer have been made with the osmotic transient technique, but the quantitative validity of these measurements has been challenged. The recent introduction of a technique based on the measurement of the kinetics of 
maltose hydrolysis suggests that the thickness of this layer is $25 \mu \mathrm{m}$ in healthy individuals and $170 \mu \mathrm{m}$ in patients with celiac disease (165). This greater resistance to the diffusion of nutrients from the intestinal lumen up to the BBM may contribute to the malabsorption that occurs in celiac disease.

Clinical manifestations: The active component of gluten is a complex mixture of glutamine- and prolamine-rich proteins called alpha-gliadin. The injurious constituent of gluten is alpha-gliadin, and although wheat, rye and barley are harmful to the small intestinal mucosa, patients with celiac disease may safely ingest maize and rice, and probably modest amounts of oats (166). A gluten-free diet improves nutritional parameters in patients with celiac disease as measured by anthropometry and/or body composition (167).

Clinical learning point: Patients with celiac disease may ingest maize and rice, and possibly small amounts of oats.

Latent celiac disease may be defined as apparently normal jejunal histology on a gluten-containing diet, but with a gluten-sensitive enteropathy diagnosed at some other time before or since. A flat jejunal biopsy may develop with a gluten challenge and may recover on a gluten-free diet (168). A number of markers have been proposed to identify patients with latent celiac disease, such as an increased number of IELs, or the presence of serum EMAs and high levels of AGA. In 10 patients with symptoms suggestive of celiac disease, positive serum EMA and a normal mucosal architecture, immunohistochemical detection of mucosal immune response was found with HLA types not commonly associated with celiac disease (169). These patients should undergo multiple small bowel biopsies, and a trial with a gluten-free diet may be encouraged to detect gluten dependency.

Clinical learning point: Gluten-sensitive celiac-like symptoms may occur in rare patients with serum EMAs, apparently normal mucosa and HLA typing not commonly associated with celiac disease. Sophisticated immunohistochemical studies need to be performed on multiple biopsies.

Reversal of the jejunoileal fold pattern ('jejunization of the ileum') is common in patients with celiac disease; partial or complete jejunoileal fold pattern reversal was identified retrospectively in 24 of 28 small bowel examinations performed on patients with celiac disease (170).

Purposeful or inadvertent continued intake of gluten is a cause of continued diarrhea in patients with celiac disease. Concurrent diagnoses need to be excluded including microscopic colitis, steatorrhea secondary to exocrine pancreatic insufficiency, dietary lactose or fructose malabsorption, anal sphincter dysfunction causing fecal incontinence and the irritable bowel syndrome (171). Approximately one-third of children with newly diagnosed celiac disease have impaired exocrine pancreatic secretion, and during the gluten-free diet a progressive reduction in the percentage of patients with subnormal fecal chymotrypsin values is observed (172).

Management of patients with nonresponsive celiac disease has been reviewed (173). After voluntary or inadvertent gluten ingestion has been excluded, and intolerances to other dietary constituents such as milk or soya have been considered, a patient with celiac disease with recurrence of symptoms should be investigated for possible pancreatic insufficiency, enteropathy-associated $\mathrm{T}$ cell lymphoma or ulcerative jejunitis. Patients with chronic ulcerative nongranulomatous jejunoileitis may present with chronic diarrhea and be found on biopsy to have varying degrees of villous atrophy (174).

Clinical learning point: Reappearance of GI symptoms in a patient with proven celiac disease raises the possibility of dietary indiscretion, or the development of complications of the enteropathy such as pancreatic insufficiency, lymphoma or ulcerative jejunitis.

Nonintestinal symptoms are common in patients with celiac disease, and there may be a long delay before an intestinal disorder is diagnosed correctly (175). Women with celiac disease are susceptible to reproductive difficulties such as infertility and miscarriages (176). Osteopenia may be due to osteomalacia, osteoporosis or secondary hyperparathyroidism. Osteopenia is common in patients with celiac disease and may improve on a gluten-free diet (177-180). Remineralization is more pronounced in celiac disease patients who better comply with a gluten-free diet, in premenopausal women and in patients with the lowest baseline bone mineral density (181).

Dermititis herpetiformis (DH) is a lifelong, glutensensitive blistering skin disease that can be controlled by dapsone. About $80 \%$ of DH patients have villus atrophy, and the remainder show increased amounts of gamma/delta receptor-bearing $\mathrm{T}$ lymphocytes in the jejunal mucosa. Celiac disease patients have an increased risk of malignancy, and $\mathrm{DH}$ patients have an increased incidence of non-Hodgkin's lymphoma. Patients with DH treated with a gluten-free diet are spared this serious complication (182). Enteropathy-associated $\mathrm{T}$ cell lymphoma arises on a background of gluten-sensitive enteropathy, with evolution of neoplastic $T$ cell clones from the reactive $T$ cell population present in the enteropathic bowel (183).

\section{LIPID ABSORPTION AND INTESTINAL LIPOPROTEINS}

Fatty acid binding proteins: The cellular and molecular aspects of fat metabolism in the intestine have been reviewed (184). The rapid transmembrane permeation of long chain fatty acids (LCFA) in the protonated form occurs by a flipflop process across the lipid bilayer of the BBM. Esterification of the LCFA with coenzyme A occurs inside the enterocyte, and the LCFA thereby becomes unavailable for diffusion back across the BBM. This contributes to the unidirectional vectorial aspects of fatty acid transport. Absorption of the 
fatty acid anion surrogate dodecyl sulphate increases in direct proportion to water absorption, suggesting a contribution of solvent drag, with a second component occurring in the absence of water absorption (185). LCFAs are taken up across the intestinal BBM by passive diffusion, as well as by a saturable process involving the BBM FABP (M-FABP) and the fatty acid transporter (FAT). M-FABP is a $40 \mathrm{kDa}$ protein, and FAT is a $88 \mathrm{kDa}$ membrane protein. Once within the cell, LCFAs bind to one of two 14 to $15 \mathrm{kDa}$ cytosolic proteins, either the liver cytosolic fatty acid binding protein (L-FABP) or I-FABP. FAT mRNA is constitutively expressed in the epithelial cells of the upper two-thirds of the villus and is restricted to the BBM (186). A sunflower oilenriched diet and treatment with the hypolipemic drug bezafibrate increase FAT mRNA abundance. FAT and FABP are coexpressed in enterocytes and may have complementary functions during dietary fat absorption.

Clinical learning point: FABPs in the BBM or in the cytosol of enterocytes may play a role in lipid absorption.

The nuclear magnetic resonance structure of I-FABP has been defined (187). I-FABP has a single binding site for LCFA, whereas L-FABP has one, two or even three fatty acid binding sites. L- but not I-FABP can bind a number of other endogenous hydrophobic ligands, including monoacylglycerol, whereas I-FABP appears to bind primarily LCFA. Both L- and I-FABP have similar affinities for saturated LCFA, but L-FABP has a fivefold greater affinity than I-FABP for unsaturated LCFA. The rate of transfer of fluorescent anthroyloxy fatty acids from these proteins to model membranes demonstrates faster transfer from I-FABP than from L-FABP. Transfer of lipid from I-FABP is independent of ionic strength, is directly dependent on the concentration of acceptor membrane vesicles and is regulated by the lipid composition of the membranes (188).

Fatty acid transfer from I-FABP to membranes occurs by direct collisional interaction of the protein with the phospholipid bilayer, whereas L-FABP transfer is by an aqueous diffusion-mediated process. I-FABP binds a single molecule of LCFA in an enclosed cavity surrounded by two antiparallel beta-sheets (189). The alpha-helices of I-FABP are not required to maintain the integrity of the fatty acid binding cavity but may serve to regulate the affinity of fatty acid binding by selectively altering the dissociation rate constant. The helical domain is not a required element of the betaclam topology of I-FABP, and the helical domain does not appear to serve as a nucleation site for the refolding process (190). The kinetics of fatty acid interactions with the FABPs from adipocytes, heart and intestine involve similar mechanisms (191).

There is a polymorphism of the gene that encodes IFABP. The 54 alanine threonine substitution in I-FABP alters the rate of intracellular fatty acid transport (192). Pima Indians (a population with a high prevalence of obesity, insulin resistance and noninsulin-dependent diabetes mellitus) have the ${ }^{54}$ threonine-encoding I-FABP genotype. The observed increases in transport of fatty acids across cells expressing ${ }^{54}$ threonine suggest a plausible physiological mechanism for these clinical observations.

I-FABP expression increases triacylglycerol and cholesteryl ester mass but has no effect on phospholipid mass in mouse $\mathrm{L}$ cell fibroblasts transfected with the cDNA encoding for I-FABP (193). TGF- $\beta_{1}$ deficiency is associated with a threefold decrease in I-FABP. This suggests that TGF- $\beta_{1}$ regulates the expression of I-FABP in the proximal intestine as well as L-FABP in the liver (194). The proinflammatory cytokines also decrease apolipoprotein (apo) beta and triacylglycerol secretion, and may thereby reduce lipid absorption (195). It is unknown whether modifying the abundance of M-FABP, FAT, or I- or L-FABP alters lipid absorption.

Bile acids: Passive transport of bile acids is dependent on their lipophilic properties, whereas conjugated bile acids are actively transported in the ileum by a carrier (196). The bile acid transporter in the ileum, a sodium-dependent homotetramer carrier composed of four subunits, has been cloned (197). It is expressed abruptly in the rat ileum at the time of weaning, and the developmental regulation is characterized by transcriptionally regulated increases in mRNA and protein levels (198). Ileal lipid-binding protein (ILBP), a $17 \mathrm{kDa}$ protein, serves as a cytosolic carrier for bile acids. Ileal lipidbinding protein is identical to a peripheral membraneassociated protein that has been cloned (199).

Clinical learning point: Genetic defects in the ileal bile acid transporter may lead to malabsorption of bile acids and lipids, and to colonic secretory diarrhea.

Bile acids are carried by portal blood to the liver where they inhibit hepatic cholesterol 7alpha-hydroxylase, the rate-limiting enzyme for the conversion of cholesterol to bile acids. Thus, the intestinal bile acid recycling process is an important regulator of the concentration of serum cholesterol. Transposition of the ileum to the proximal intestine attenuates cholesterol absorption and transport, presumably by the transposition promoting premature absorption of bile acids, thereby affecting micellar solubilization and uptake of lipids by the small intestine (200).

Bile acid absorption measured by the selena homotaurocholic acid test is not altered in patients with chronic cholestasis, but treatment with ursodeoxycholic acid results in a decrease in the selena homotaurocholic acid percentage retention (201). Intestinal bacteria transform bile acids and sterols, and feeding rats beta-lactam antibiotics decreases the number of fecal anaerobic microbes, decreases the secondary bile acids and increases primary bile acids. These effects slowly recover after the antibiotics are stopped (202).

Cholesterol: Intestinal alkaline phosphatase is secreted bound to surfactant-like particles, which can be localized by electron microscopy to the basolateral space of the enterocyte and to the intestinal lumen. Surfactant-like particles are secreted into the basolateral space in Caco-2 cells and are then transported to the intestinal lumen through the tight junctions between enterocytes (203). 
The bile salt-dependent cholesteryl ester hydrolase increases the uptake of cholesterol from micellar-esterified cholesterol but has less effect on the uptake of micellar-free cholesterol (204). Increasing the viscosity of the intestinal contents reduces dietary cholesterol absorption and plasma cholesterol concentration (205).

There are considerable interindividual responses of plasma cholesterol and lipoprotein concentrations to dietary changes. These differences may have a genetic basis, relating to variations in dietary cholesterol absorption and in the rate of conversion of cholesterol to bile acids and their subsequent excretion (206). Cholesterol absorption is decreased after a $75 \%$ proximal resection of porcine small intestine, and cholesterol absorption efficiency gradually increases postoperatively (207). In resected and in control animals, villus height correlates positively with cholesterol absorption efficiency. Some unesterified polyunsaturated fatty acids can be absorbed into the enterocyte from the blood; this may represent an important source of eicosanoid precursors in the GI tract (208). Biliary phospholipid is also an important source of arachidonic acid for the small intestine (209).

The absorption of beta-sitosterol is approximately $10 \%$ that of cholesterol, despite differing from cholesterol by only an ethol group on carbon 24. Beta-sitosterol has no effect on cholesterol trafficking or on cholesteryl ester secretion in Caco-2 cells. However, cholesterol synthesis and hydroxymethylglutaryl coenzyme A reductase activities are decreased in cells incubated with beta-sitosterol, associated with a decrease in reductase mass and mRNA levels (210).

Intracellular transport of beta-carotene is not mediated by cytosolic transport proteins (used for the intermembrane transport of phospholipids, cholesterol and alpha-tocopherol) but occurs by other mechanisms such as vessicular transport or by membrane-bound proteins (211). The major pathway for formation of vitamin A from beta-carotene in the rat intestine is central cleavage (212).

In contrast to results from earlier studies using watersoluble markers, newer evidence suggests that the absorption of lipids is not complete in the proximal intestine and that the intestinal length required for fat absorption depends upon the load of fat in the diet (213).

Intestinal proteins: The major lipoproteins produced by the small intestine are chylomicrons, very low density lipoproteins (VLDL) and high density lipoproteins (HDL). Apolipoproteins are the peptide surface components of lipoprotein particles. They serve essential functions in the secretion, metabolism and receptor-mediated uptake of these particles. Apo B and apo A-1 are the major apolipoproteins expressed by both the liver and small intestine. Apo B-100 contains the low density lipoprotein (LDL) receptor binding domain, whereas the smaller apo B-48 does not. Both forms of apo B are derived from the same gene by a unique post-transcriptional mRNA editing process. Apo B-48 is present in chylomicrons and chylomicron remnants, and apo B-48 is necessary for the packaging of dietary lipids into chylomicrons.

Apo B-48 participates in the formation and/or transport of chylomicrons after the absorption of long chain triglyc- erides (214). Undifferentiated cultured intestinal epithelial cells (IPEC-1) synthesize and secrete only apo B-100, but both apo B-100 and apo B-48 are produced by differentiated cells. This suggests that an intracellular pool of apolipoprotein with a slow turnover is mobilized for secretion and in response to fatty acid uptake (215).

Apo A-IV is synthesized in the small intestine and is packaged in intestinal chylomicrons. Apo A-IV is the major apolipoprotein of plasma HDL and is produced by both the liver and intestine. Apo A-IV stimulates lipoprotein lipase, serves as a cofactor of lecithin-cholesterol acyltransferase (the enzyme responsible for the production of cholesteryl ester in circulating HDL) and may play a role in reverse cholesterol transport. Apo A-IV may be important as a satiety factor after a lipid meal (216). Apo A-IV is regulated by medium chain triglyceride absorption. Fatty acid re-esterification and lipoprotein assembly are not prerequisites for this regulation.

Long chain polyunsaturated dietary lipid absorption acutely up-regulates small intestinal apolipoprotein expression in the newborn piglet, and intestinal apo B and A-1 expression is differentially regulated by dietary lipid by co- and post-translational mechanisms (217). Stimulation of apo A-IV by dietary fat depends upon the transport of absorbed lipid via chylomicrons in lymph (218).

The signal transduction mechanisms involving the control of apolipoprotein genes have been examined (219). LDL receptor mRNA is produced in the villus cells, and the regulation by fat feeding is at the level of transcription (220). Expression of LDL receptor mRNA in villus cells of the ileum is higher than that in the jejunum. Apo B mRNA editing, a post-transcriptional site-specific reaction, is mediated by a protein complex that has been cloned. Components of the apo B mRNA editing complex are widely distributed and regulate editing in a tissue-specific manner (221).

The detergent Pluronic L-81 (Sigma-Aldrich Corporation, Missouri) reduces serum VLDL and LDL concentrations. Pluronic L-81 ameliorates diet-induced atherogenesis in experimental animals by blocking mesenteric lipoprotein secretion at a pre-Golgi stage, without interfering with initial cholesterol and fatty acid uptake or re-esterification. Treatment with Pluronic L-81 traps lipids within enterocytes, and leads to cytosolic and ER lipid accumulation. Also, Pluronic L-81 reduces chylomicron formation without any major compositional change in the chylomicrons themselves (222).

The triglyceride fatty acid composition of the enterocyte, the cell of origin of the chylomicron, differs from that of dietary triglyceride, suggesting an extraintestinal source of this lipid. This extraintestinal source may include uptake by the enterocyte of circulating fatty acids as well as the chylomicron remnant (the particle resulting from the lipolysis of chylomicron triglyceride by lipoprotein lipase). The chylomicron remnant particles display apo $E$ on their surface, bind to the LDL receptor (also called the apo B-100/E receptor) and may thereby provide a source of endogenous triglyceride fatty acids for the enterocyte (223). 
The genetic basis of primary disorders of intestinal fat transport have been reviewed (224). Trans fatty acidinduced hypercholesterolemia is not due to altered intestinal absorption or transport of cholesterol (225). The formation of chylomicrons by the intestine is important for the absorption of dietary fats and fat-soluble vitamins. Apo B is essential for the formation of chylomicrons in the intestine. In genetically modified mice that do not express apo B in the intestine, electron microscopy of the enterocytes shows cells that are engorged with fat in the cytosol. This arises because these animals lack nascent chylomicrons in the ER and Golgi apparatus (226).

\section{REFERENCES}

1. McGowan I, Anton P. AIDS and intestinal disease. Curr Opin Gastroenterol 1997;13:18-23.

2. Watson A, Samore MH, Wanke CA. Diarrhea and quality of life in ambulatory HIV-infected patients. Dig Dis Sci 1996;41:1794-800.

3. Bjarnason I, Sharpstone DR, Francis N, et al. Intestinal inflammation, ileal structure and function in HIV. AIDS 1996;10:1385-91.

4. Feng Y, Broder CC, Kennedy PE, Berger EA. HIV-1 entry cofactor: functional cDNA cloning of a seven-transmembrane, G protein-coupled receptor. Science 1996;272:872-7.

5. Alkhatib G, Combadiere C, Broder CC, et al. CC-CKR5: A RANTES, MIP-1, MIP-1 receptor as a fusion cofactor for macrophage-tropic HIV-1. Science 1996;272:1955-8.

6. Heath SL, Tew JG, Szakal AK, Burton GF. Follicular dendritic cells and human immunodeficiency virus infectivity. Nature 1995;377:740-4.

7. Wilcox CM, Schwartz DA, Cotsonis G, Thompson SE. Chronic unexplained diarrhea in human immunodeficiency virus infection: determination of the best diagnostic approach. Gastroenterology 1996;110:30-7.

8. Blanshard C, Francis N, Gazzard BG. Investigation of chronic diarrhea in acquired immunodeficiency syndrome. A prospective study of 155 patients. Gut 1996;39:824-32.

9. Blackman E, Binder S, Gaultier C, Benveniste R, Cecilio M. Cryptosporidiosis in HIV-infected patients: diagnostic sensitivity of stool examination, based on number of specimens submitted. Am J Gastroenterol 1997;92:451-3.

10. Vakil NB, Schwartz SM, Buggy BP, et al. Biliary cryptosporidiosis in HIV-infected people after the waterborne outbreak of cryptosporidiosis in Milwaukee. N Engl J Med 1996;334:19-23.

11. Cotte L, Drouet E, Bailly F, Vitozzi S, Denoyel GA, Trepo C. Cytomegalovirus DNA level on biopsy specimens during treatment of cytomegalovirus gastrointestinal disease. Gastroenterology 1996;111:439-44.

12. De Maar EF, Kleibeuker JH, Boersma-van Ek W, The TH, van Son WJ. Increased intestinal permeability during cytomegolovirus infection in renal transplant recipients. Transpl Int 1996;9:576-80.

13. Rabeneck L, Genta RM, Risser JMH, Bailey ME, Clarridge JE, Gyorkey F. Uncertain clinical significance of duodenal mucosal abnormalities in HIV-infected individuals. J Clin Gastroenterol 1996;23:11-4.

14. Sharpstone D, Rowbottom A, Francis N, et al. Thalidomide: a novel therapy for microsporidiosis. Gastroenterology 1997;112:1823-9.

15. Winter $\mathrm{H}$. Gastrointestinal tract function and malnutrition in HIV-infected children. J Nutr 1996;126:2620S-2S.

16. MacAllan DC, Noble C, Baldwin C, et al. Energy expenditure and wasting in human immunodeficiency virus infection. N Engl J Med 1995;333:83-8.

17. Mantyh CR, Pappas TN, Lapp JA, et al. Substance P activation of enteric neurons in response to intraluminal Clostridium difficile toxin $\mathrm{A}$ in the rat ileum. Gastroenterology 1996;111:1272-80.

18. Sternini C, Su D, Gamp PD, Bunnett NW. Cellular sites of expression of the neurokinin-1 receptor in the rat gastrointestinal tract. J Comp Neurol 1995;358:531-40.

19. Castagliuolo I, LaMont JT, Qiu B, Nikulasson ST, Pothoulakis C. A receptor decoy inhibits the enterotoxic effects of Clostridium difficile toxin A in rat ileum. Gastroenterology 1996;111:433-8.
In the early stages of inflammation, even before absorptive cells are morphologically damaged, absorption of lipids decreases due to a direct interaction of proinflammatory cytokines within the enterocytes, likely as a result of TNF- $\alpha$, IL-1- $\beta$ and IL-6, decreasing apo B and triacylglycerol secretion (195). IL-6 releases EGF or EGF-like molecules that bind to cell surface receptors and cause a decline in triacylglycerol and apo B secretion.

Clinical learning point: Inflammatory cytokines may alter lipid and apolipoprotein secretion from enterocytes.

20. McClean P, Dodge JA, Nunn S, Carr KE, Sloan JM. Surface features of small intestinal mucosa in chidhood diarrheal disorders. J Pediatr Gastroenterol Nutr 1996;23:538-46.

21. Ilnyckyj A, Greenberg H, Bernstein CN. Escherichia coli 0157:H7 infection mimicking Crohn's disease. Gastroenterology 1997;112:995-9.

22. Giannella RA. Escherichia coli heat-stable enterotoxins, guanylins, and their receptors: what are they and what do they do? J Lab Clin Med 1995;125:173-81.

23. Scheving LA, Russell WE, Chong K-M. Structure, glycosylation, and localization of rat intestinal guanylyl cyclase C: modulation by fasting. Am J Physiol 1996;271:G959-68.

24. Savidge TC, Shmakov AN, Walker-Smith JA, Phillips AD. Epithelial cell proliferation in childhood enteropathies. Gut 1996;39:185-93.

25. Lencer WI, Moe S, Rufo PA, Madara JL. Transcytosis of cholera toxin subunits across model human intestinal epithelia. Proc Natl Acad Sci USA 1995;92:10094-8.

26. Benard O, Balasubramanian KA. Effect of enterotoxin on glutathione status in the intestinal mucosa. J Biochem Biophys 1996;33:409-13.

27. Qiu B, Pothoulakis C, Castagliuolo I, Nikulasson Z, LaMont JT. Nitric oxide inhibits rat intestinal secretion by Clostridium difficile toxin A but not Vibrio cholerae enterotoxin. Gastroenterology 1996;111:409-18.

28. Fasano A, Noriega FR, Liao FM, Wang W, Levine MM. Effect of shigella enterotoxin 1 (ShET1) on rabbit intestine in vitro and in vivo. Gut 1997;40:505-11.

29. Dalton CB, Austin CC, Sobel J, et al. An outbreak of gastroenteritis and fever due to Listeria monocytogenes in milk. N Engl J Med 1997;336:100-5.

30. Sarem F, Sarem-Damerdji LO, Nicolas JP. Comparison of the adherence of three Lactobacillus strains to Caco-2 and Int-407 human intestinal cell lines. Lett Appl Microbiol 1996;22:439-42.

31. Mao Y, Nobaek S, Kasravi B, et al. The effects of Lactobacillus strains and oat fiber on methotrexate-induced enterocolitis in rats. Gastroenterology 1996;111:334-44.

32. Cartwright-Shamoon J, Dickson GR, Dodge J, Carr KE. Uptake of yeast (Saccharomyces boulardii) in normal and rotavirus treated intestine. Gut 1996;39:204-9.

33. Matsui SM, Angel J. Viral infections of the gastrointestinal tract. Curr Opin Gastroenterol 1997;13:57-63.

34. Rickman LS, Freeman WR, Green WR, et al. Brief report: uveitis caused by Tropheryma whippelii. N Engl J Med 1995;332:363-6.

35. Schilling D, Adamek HE, Kaufmann V, Maier M, Riemann JF. Arthralgia as an early extraintestinal symptom of Whipple's disease. J Clin Gastroenterol 1997;24:18-20.

36. Von Herbay A, Ditton H-J, Maiwald M. Diagnostic application of a polymerase chain reaction assay for the Whipple's disease bacterium to intestinal biopsies. Gastroenterology 1996;110:1735-43.

37. Ramzan NN, Loftus E Jr, Burgart LJ, et al. Diagnosis and monitoring of Whipple disease by polymerase chain reaction. Ann Intern Med 1997;126:520-7.

38. Müller C, Petermann D, Stain C, et al. Whipple's disease: comparison of histology with diagnosis based on polymerase chain reaction in four consecutive cases. Gut 1997;40:425-7.

39. Perdue MH, McKay DM. Mucosal regulators and immunopathophysiology. Curr Opin Gastroenterol 1996;12:591-9. 
40. Fiocchi C. Cytokines and intestinal inflammation. Transplant Proc 1996;28:2442-3.

41. Madsen KL, Tavernini MM, Mosmann TR, Fedorak RN. Interleukin 10 modulates ion transport in rat small intestine. Gastroenterology 1996;111:936-44.

42. Jung HC, Eckmann L, Yang S, et al. A distinct array of proinflammatory cytokines is expressed in human colon epithelial cells in response to bacterial invasion. J Clin Invest 1995;95:55-65.

43. Chen Y, Inobe J, Marks R, Gonnella P, Kuchroo VK, Weiner HL. Peripheral deletion of antigen-reactive $\mathrm{T}$ cells in oral tolerance. Nature 1995;376:177-80.

44. Powrie F, Carlino J, Leach MW, Mauze S, Coffman RL. A critical role for transforming growth factor-beta but not interleukin 4 in the suppression of T helper type 1-mediated colitis by CD45RB ${ }^{\text {low }} \mathrm{CD} 4+$ T cells. J Exp Med 1996;183:2669-74.

45. Jepson MA, Clark MA, Foster N, et al. Targeting to intestinal M cells. J Anat 1996;189:507-16.

46. Fló J, Elías F, Benedetti R, Massouh E. Reversible effects on B and T cells of the gut-associated lymphoid tissues in rats malnourished during suckling: impaired induction of the immune response to intra-Peyer patches immunization with cholera toxin. Clin Immunol Immunpathol 1996;80:147-54.

47. Wilson AD, Haverson K, Southgate K, Bland PW, Stokes CR, Bailey M. Expression of major histocompatibility complex class II antigens on normal porcine intestinal endothelium. Immunology 1996;88:98-103.

48. Kearsey JA, Stadnyk AW. Isolation and characterization of highly purified rat intestinal intraepithelial lymphocytes. J Immunol Methods 1996;194:35-48.

49. Kawaguchi-Miyashita M, Shimizu K, Nanno M, et al. Development and cytolytic function of intestinal intraepithelial $\mathrm{T}$ lymphocytes in antigen-minimized mice. Immunology 1996;89:268-73.

50. Seta-Tsukinowa. Regulation of complement C3 synthesis by interleukin-1 and transforming growth factor-beta in rat non-transformed intestinal epithelial cell line, IEC. J Gastroenterol 1996;31:633-8.

51. Teitelbaum DH, Del Valle J, Reyas B, et al. Intestinal intraepithelial lymphocytes influence the production of somatostatin. Surgery 1996;120:227-33.

52. Snijders F, Meenan J, Van den Blink B, Van Deventer SJG, Ten Kate FJW. Duodenal intraepithelial and lamina propria T lymphocytes in human immunodeficiency virus-infected patients with and without diarrhea. Scand J Gastroenterol 1996;31:1176-81.

53. Nilssen DE, Müller F, Øktedalen O, et al. Intraepithelial / T cells in duodenal mucosa are related to the immune state and survival time in AIDS. J Virol 1996;70:3545-50.

54. Roberts AI, Bilenker M, Ebert EC. Intestinal intraepithelial lymphocytes have a promiscuous interleukin-8 receptor. Gut 1997;40:333-8.

55. Hogaboam CM, Snider DP, Collins ST. Cytokine modulation of T-lymphocyte activation by intestinal smooth muscle cells. Gastroenterology 1997;112:1986-95.

56. Powers DC, McElhaney JE, Florenda OA Jr, et al. Humoral and cellular immune responses following vaccination with purified recombinant hemaglutinin from influenza A (H3N2) virus. J Infect Dis 1997;175:342-51.

57. Michalsky MP, Deitch EA, Ding J, Lu Q, Huang Q. Interleukin-6 and tumor necrosis factor production in an enterocyte cell model (Caco-2) during exposure to Escherichia coli. Shock 1997;7:139-46.

58. Miura S, Tsuzuki Y, Kurose I, et al. Endotoxin stimulates lymphocyte-endothelial interactions in rat intestinal Peyer's patches and villus mucosa. Am J Physiol 1996;271:G282-92.

59. Quigley EMM. Small intestinal transplantation: reflections on an evolving approach to intestinal failure. Gastroenterology 1996;110:2009-12.

60. Yedidag EN, Fryer JP, Levi E, et al. Early histopathology of small intestinal discordant xenografts. Transplantation 1996;62:1385-91.

61. Lee RG, Nakamura K, Tsamandas AC, et al. Pathology of human intestinal transplantation. Gastroenterology 1996;110:1820-34.

62. Rahman MS, Taguchi T, Nakao M, Yamada T, Suita S. Morphologic and functional comparison of jejunal and ileal segmental grafts in rat small intestinal transplantation: long-term results. Transplant Proc 1996;28:2551.

63. Nüssler NC, Cicalese L, Hoffman RA, et al. CD8+ host cells infiltrate the intestinal mucosa after allogeneic small bowel transplantation even in the abscence of acute rejection. Transplant Proc 1996;28:2456.

64. Sullivan B, Cohen Z, Fu X-M, et al. Graft-infiltrating cells in rats receiving orthotopic semiallogeneic small intestine transplantation with portal or systemic venous drainage. Transplantation 1996;62:715-21.

65. Miura S, Fukumura K, Kurose I, et al. Roles of ET-1 in endotoxininduced microcirculatory disturbance in rat small intestine. Am J Physiol 1996;271:G461-9.

66. Wallis $G$, Brackett $D$, Lerner $M$, et al. In vivo spin trapping of nitric oxide generated in the small intestine, liver, and kidney during the development of endotoxemia: a time-course study. Shock 1996;6:274-8.

67. Wells CL. Colonization and translocation of intestinal bacterial flora. Transplant Proc 1996;28:2653-6.

68. Spada M, Alessiani M, Fabbi M, et al. Bacterial translocation is enhanced in pig intestinal transplantation when the colon is included in the graft. Transplant Proc 1996;28:2658-9.

69. Pirenne J, Benedetti E, Gruessner A, et al. Combined transplantation of small and large bowel. Transplantation 1996;61:1685-94.

70. Lòpez F, Hernandez G, Castillo L, et al. Effect of antibiotic luminal flushing on bacterial translocation: experimental study in small bowel autotransplantation in dogs. Transplant Proc 1996;28:2642-3.

71. Kuo RC, Marks WH, Lieberman JM, Johnson DL, Alfrey EJ, Dafoe DC. Systemic inflammatory response syndrome after human syngeneic intestinal transplantation: evidence for disruption of enterocyte barrier function. Transplant Proc 1996;28:2763-4.

72. Kanda T, Fujii $\mathrm{H}$, Tani $\mathrm{T}$, et al. Intestinal fatty acid-binding protein is a useful diagnostic marker for mesenteric infarction in humans. Gastroenterology 1996;110:339-43.

73. Sarr MG. Motility and absorption in the transplanted gut. Transplant Proc 1996;28:2535-9.

74. Hamada N, Hutson WR, Nakada K, et al. Intestinal neuromuscular function after preservation and transplantation. J Surg Res 1996;63:460-6.

75. Costa A, Alessiani M, De Ponti F, et al. Stimulatory effect of FK506 and erythromycin on pig intestinal motility. Transplant Proc 1996;28:2571-2

76. Cicalese L, Weber K, Lee RG, Rakela J, Tabasco-Minguillán J. Effect of FK506 on the mucosal perfusion of the rat intestinal allograft. Transplant Proc 1996;28:2575.

77. Oishi AJ, Inoue Y, Souba WW, Sarr MG. Alterations in carrier-mediated glutamine transport after a model of canine jejunal autotransplantation. Dig Dis Sci 1996;41:1915-24.

78. Winkler GB, Smith LJ, Sigalet DL. Fat absorption following small intestinal transplantation. Transplant Proc 1996;28:2544.

79. Saito T, Kobayashi E, Kaneko K, Miyata M, Fujimura A. Lipid absorption of the allointestinal grafts under a short course of methyldeoxysupergualin. Transplant Proc 1996;28:2570.

80. Terao T, Hisanaga E, Sai Y, Tamai I, Tsuji A. Active secretion of drugs from the small intestinal epithelium in rats by P-glycoprotein functioning as an absorption barrier. J Pharm Pharmacol 1996:48:1083-9.

81. Vanner S, Surprenant A. Neural reflexes controlling intestinal microcirculation. Am J Physiol 1996;271:G223-30.

82. Tsuruma T, Yagihashi A, Hirata K, et al. Evaluation of plasma IL-8 (CINC) concentration during ischemia and after reperfusion in the small intestine. Transplant Proc 1996;28:1917-8.

83. Fukumura D, Miura S, Kurose I, et al. IL-1 is an important mediator for microcirculatory changes in endotoxin-induced intestinal mucosal damage. Dig Dis Sci 1996;41:2482-92.

84. McCarthy-Pastores S, Katz DP, Kvetan V. Splanchnic ischemia and gut mucosal injury in sepsis and the multiple organ dysfunction syndrome. Am J Gastroenterol 1996;91:1697-710.

85. Fan WQ, Smolich JJ, Wild J, Yu VYH, Walker AM. Nitric oxide modulates regional blood flow differences in the fetal gastrointestinal tract. Am J Physiol 1996;271:G598-604.

86. Bohlen HG, Lash JM. Intestinal absorption of sodium and nitric oxide-dependent vasodilation interact to dominate resting vascular resistance. Circ Res 1996;78:231-7.

87. Schleiffer R, Raul F. Prophylactic administration of L-arginine improves the intestinal barrier function after mesenteric ischaemia. Gut 1996;39:194-8.

88. Kreienberg PB, Darling RC III, Shah DM, Vincent PA, Blumenstock FA. ATP-MgC12 reduces intestinal permeability during mesenteric ischemia. J Surg Res 1996;66:69-74. 
89. Miyauchi T, Tomobe Y, Ishikawa T, Goto K, Sugishita Y. Vasoconstriction by endothelin-1 in resistance and conduit portions of isolated human mesenteric arteries. Eur J Pharmacol 1996;303:193-6.

90. Åneman A, Medbak S, Watson D, Haglind E. Met-enkephalin and catecholamine release during feline intestinal ischemia-reperfusion. Shock 1996;4:4334-439.

91. LeGrand TS, Aw TY. Chronic hypoxia, glutathione-dependent detoxication, and metabolic instability in rat small intestine. Am J Physiol 1997;272:G328-34.

92. Ikai M, Itoh M, Joh T, Yokoyama Y, Odada N, Okada H. Complement plays an essential role in shock following intestinal ischemia in rats. Clin Exp Immunol 1996;106:156-9.

93. Pujic Z, Matsumoto I, Yamataka A, Miyano T, Wilce P. Induction of immediate-early, ornithine decarboxylase and antizyme gene expression in the rat small intestine after transient ischaemia. Life Sci 1996;58:2289-96.

94. Sonnino RE, Pigatt L, Schrama A, Burchett S, Franson R. Phospholipase $A_{2}$ secretion during intestinal graft ischemia. Dig Dis Sci 1997;42:972-81.

95. Yagi, M, Tani T, Hashimoto T, Shimizu K, Miyazaki I. Effect of prostaglandin $\mathrm{E}_{1}$ on acute ischemia-reperfusion of canine small intestine. J Clin Biochem Nutr 1996;21:39-44.

96. Maconi G, Imbesi V, Porro GB. Doppler ultrasound measurement of intestinal blood flow in inflammatory bowel disease. Scand J Gastroenterol 1996;31:590-3.

97. Battarbee HD, Grisham MB, Johnson GG, Zavecz HJ. Superior mesenteric artery blood flow and indomethacin-induced intestinal injury and inflammation. Am J Physiol 1996;271:G605-12.

98. Frager D, Baer JW, Medwid SW, Rothpearl A, Bossart P. Detection of intestinal ischemia in patients with acute small-bowel obstruction due to adhesions or hernia: efficacy of CT. AJR Am J Roentgenol 1996;166:67-71.

99. Taourel PG, Fabre J-M, Pradel JA, et al. Value of CT in the diagnosis and management of patients with suspected acute small-bowel obstruction. AJR Am J Roentgenol 1995;165:1187-92.

100. Taourel PG, Deneuville M, Pradel JA, Regent D, Bruel JM. Acute mesenteric ischemia: diagnosis with contrast-enhanced CT. Radiology 1996;199:632-6.

101. Teefey SA, Roarke MC, Brink JA, et al. Bowel wall thickening: differentiation of inflammation from ischemia with color Doppler and duplex US. Radiology 1996;198:547-51.

102. Bielefeldt K, Conklin JL. Intestinal motility during hypoxia and reoxygenation in vitro. Dig Dis Sci 1997;42:878-84.

103. Golino A, Crawford EM, Gathe JC, Dekmezian RH. Recurrent small bowel infarction associated with antithrombin deficiency. Am J Gastroenterol 1997;92:323-5.

104. MacLeod RJ, Hamilton JR. Activation of $\mathrm{Na}+/ \mathrm{H}+$ exchange is required for regulatory volume decrease after modest "physiological" volume increases in jejunal villus epithelial cells. J Biol Chem 1996;271:23138-45.

105. Cabado AG, Uy FH, Kapus A, Lukacs G, Grinstein S, Orlowski J. Distinct structural domains confer cAMP sensitivity and ATP dependence to the $\mathrm{Na}^{+} / \mathrm{H}^{+}$exchanger NHE3 isoform. J Biol Chem 1996;271:3590-9.

106. Dudeja PK, Rao DD, Syed I, et al. Intestinal distribution of human $\mathrm{Na}^{+} / \mathrm{H}^{+}$exchanger isoforms NHE-1, NHE-2, and NHE-3 mRNA. Am J Physiol 1996;271:G483-93.

107. Hines OJ, Bilchik AJ, McFadden DW, et al. $\mathrm{Na}^{+} / \mathrm{H}^{+}$exchange mediates postprandial ileal water and electrolyte transport. Dig Dis Sci 1995;40:774-80.

108. Sundaram U, West AB. Effect of chronic inflammation on electrolyte transport in rabbit ileal villus and crypt cells. Am J Physiol 1997;272:G732-41.

109. Kandasamy RA, Yu FH, Harris R, Boucher A, Hanrahan JW, Orlowski J. Plasma membrane $\mathrm{Na}^{+} / \mathrm{H}^{+}$exchanger isoforms (NHE-1, -2 , and -3 ) are differentially responsive to second messenger agonists of the protein kinase $\mathrm{A}$ and $\mathrm{C}$ pathways. J Biol Chem 1995;270:29209-16.

110. Levine SA, Nath SK, Yun CHC, et al. Separate C-terminal domains of the epithelial specific brush border $\mathrm{Na}^{+} / \mathrm{H}^{+}$exchanger isoform NHE3 are involved in stimulation and inhibition by protein kinases/growth factors. J Biol Chem 1995;270:13716-25.

111. Wakabayashi S, Ideda T, Noel J, et al. Cytoplasmic domain of the ubiquitous $\mathrm{Na}^{+} / \mathrm{H}^{+}$exchanger NHE1 can confer $\mathrm{Ca}^{2+}$ responsiveness to the apical isoform NHE3. J Biol Chem 1995;270:26460-5.
112. Chow A, Zhou W, Jacobson R. Regulation of $\mathrm{AE2} \mathrm{Cl} / \mathrm{HCO}_{3}$ exchanger during intestinal development. Am J Physiol 1996;271:G330-7.

113. D'Andrea L, Lytle C, Matthews JB, et al. Na:K:2C1 cotransporter (NKCC) of intestinal epithelial cells: surface expression in response to cAMP. J Biol Chem 1996;271:28969-76.

114. Khurana S, Nath SK, Levine SA, et al. Brush border phosphatidylinositol 3-kinase mediates epidermal growth factor stimulation of intestinal $\mathrm{NaCl}$ absorption and $\mathrm{Na}^{+} / \mathrm{H}^{+}$exchange. J Biol Chem 1996;271:9919-27.

115. Bearcroft CP, Perrett D, Farthing MJG. 5-hydroxytryptamine release into human jejunum by cholera toxin. Gut 1996;39:528-31.

116. Franks CM, Hardcastle J, Hardcastle PT. Neural involvement in 5-hydroxytryptamine-induced net electrogenic ion secretion in the rat intestine in vivo. J Pharm Pharmacol 1996;48:411-6.

117. Sanger GJ. 5-Hydroxytryptamine and functional bowel disorders. Neurogastroenterol Mot 1996;8:319-31.

118. Agrons GA, Corse WR, Markowitz RI, Suarez ES, Perry DR. Gastrointestinal manifestations of cystic fibrosis: radiologic pathologic correlation. Radiographics 1996;16:871-93.

119. Teune TM, Timmers-Reker AJM, Bouquet J, Bijman J, De Jonge HR, Sinaasappel M. In vivo measurement of chloride and water secretion in the jejunum of cystic fibrosis patients. Pediatr Res 1996;40:522-7.

120. Ameen NA, Ardito T, Kashgarian M, Marino CR. A unique subset of rat and human intestinal villus cells express the cystic fibrosis transmembrane conductance regulator. Gastroenterology 1995;108:1016-23.

121. Valverde MA, O’Brien JA, Sepúlveda FV, Ratcliff RA, Evans MJ, Colledge WH. Impaired cell volume regulation in intestinal crypt epithelia of cystic fibrosis mice. Proc Natl Acad Sci USA 1995;92:9038-41.

122. Van Kuijck MA, Vamn Aubel RAMH, Busch AE, et al. Molecular cloning and expression of a cyclic AMP-activated chloride conductance regulator: a novel ATP-binding cassette transporter. Proc Natl Acad Sci USA 1996;93:5401-6.

123. Lang ME, Davison JS, Bates SL, Meddings JB. Opioid receptors on guinea-pig intestinal crypt epithelial cells. J Physiol 1996;497:161-74.

124. Farthing MJG. The role of somatostatin analogues in the treatment of refractory diarrhea. Digestion 1996;57:107-13.

125. Harris AG, O'Dorisio TM, Woltering EA, et al. Consensus statement: octreotide dose titration in secretory diarrhea. Dig Dis Sci 1995;40:1464-73.

126. Rozé C, Molis C, Fu-Cheng X, Ropert A, Geneve J, Galmiche JP. Peptide YY inhibition of prostaglandin-induced intestinal secretion is haloperidol-sensitive in humans. Gastroenterology 1997;112:1520-8.

127. Quin JA, Sgambati SA, Goldenring JR, et al. PYY inhibition of VIP-stimulated ion transport in the rabbit distal ileum. J Surg Res 1995;58:111-5.

128. McKay DM, Berin MC, Fondacaro JD, Perdue MH. Effects of neuropeptide $\mathrm{Y}$ and substance $\mathrm{P}$ on antigen-induced ion secretion in rat jejunum. Am J Physiol 1996;271:G987-92.

129. Mourad FH, O'Donnell LHD, Andre EA, et al. L-Arginine, nitric oxide, and intestinal secretion: studies in rat jejunum in vivo. Gut 1996;39:539-44.

130. Fedorak RN. Antidiarrheal therapy. In: Friedman G, ed. Gastrointestinal Pharmacology and Therapeutics. Philadelphia: Lippincott-Raven Publishers, 1997:175-92.

131. Schiller LR, Santa Ana CA, Porter J, Fordtran JS. Glucose-stimulated sodium transport by the human intestine during experimental cholera. Gastroenterology 1997;112:1529-35.

132. Whang EE, Dunn JC, Mahanty H, McFadden DW, Zinner MJ, Ashley SW. Endotoxin inhibitor prevents sepsis-induced alterations in intestinal ion transport. Am J Surg 1996;172:341-4.

133. Molina S, Vettorazzi C, Peerson JM, Solomons NW, Brown KH. Clinical trial of glucose-oral rehydration solution (ORS), rice dextrin-ORS, and rice flour-ORS for the management of children with acute diarrhea and mild or moderate dehydration. Pediatrics 1995;95:191-7.

134. Multicentre evaluation of reduced-osmolarity oral rehydration salts solution. International Study Group on Reduced-osmolarity ORS solutions. Lancet 1995;345:282-5.

135. MacLeod RJ, Bennett HP, Hamilton JR. Inhibition of intestinal secretion by rice. Lancet 1995;346:90-2.

136. Islam S, Mahalanabis D, Chowdhury AKA, Wahed MA, Rahman ASMH. Glutamine is superior to glucose in stimulating water 
and electrolyte absorption across rabbit ileum. Dig Dis Sci 1997;42:420-3

137. Santosham M, Fayad I, Zikri MA, Hussein A, Amponsah A. A double-blind clinical trial comparing World Health Organization oral rehydration solution with a reduced osmolarity solution containing equal amounts of sodium and glucose. J Pediatr 1996; $128: 45-51$

138. Wapnir RA, Wingertzahn MA, Moyse J, Teichberg S. Gum arabic promotes rat jejunal sodium and water absorption from oral rehydration solutions in two models of diarrhea. Gastroenterology 1997;112:1979-85.

139. Liu L, Coupar IM. Role of $\alpha_{2}$-adrenoceptors in the regulation of intestinal water transport. Br J Pharmacol 1997;120:892-8.

140. Prezmioslo RT, Lundin KE, Sollid LM, Nelufer J, Ciclitira PJ. Histological changes in small bowel mucosa induced by gliadin sensitive $\mathrm{T}$ lymphocytes can be blocked by anti-interferon gamma antibody. Gut 1995;36:874-9.

141. Beckett CG, Dell'Olio D, Kontakou M, Przemioslo RT, Rosen-Bronson S, Ciclitira PJ. Analysis of interleukin-4 and interleukin-10 and their association with the lymphocytic infiltrate in the small intestine of patients with celiac disease. Gut 1996;39:818-23.

142. Kontakou M, Przemioslo RT, Sturgess RP, et al. Cytokine mRNA expression in the mucosa of treated celiac patients after wheat peptide challenge. Gut 1995;37:52-7.

143. Shidrawi RG, Day P, Przemioslo R, Ellis HJ, Nelufer JM, Ciclitira PJ. In vitro toxicity of gluten peptides in celiac disease assessed by organ culture. Scand J Gastroenterol 1995;30:758-63.

144. Stěpánková R, Tlaskalová-Hogenová H, Sinkora J, Jodl J, Frič P. Changes in jejunal mucosa after long-term feeding of germfree rats with gluten. Scand J Gastroenterol 1996;31:551-7.

145. Nilsen EM, Gjertsen HA, Jensen K, Brandtzaeg P, Lundin KEA. Gluten activation of peripheral blood $\mathrm{T}$ cells induces a Th0-like cytokine pattern in both celiac patients and controls. Clin Exp Immunol 1996;103:295-303.

146. Oberhuber G, Vogelsang H, Stolte M, Muthenthaler S, Kummer AJ, Radaszkiewicz T. Evidence that intestinal intraepithelial lymphocytes are activated cytotoxic $T$ cells in celiac disease but not in giardiasis. Am J Pathol 1996;148:1351-7.

147. Troncone R, Greco L, Mayer M, et al. In siblings of celiac children, rectal gluten challenge reveals gluten sensitization not restricted to celiac HLA. Gastroenterology 1996;111:318-24.

148. Marquez MG, Roux ME. Intestinal intraepithelial lymphocytes are influenced by luminal antigens. Comunicaciones Biologicas 1995;13:313-9.

149. Maiuri L, Picarelli A, Boirivant M, et al. Definition of the initial immunologic modifications upon in vitro gliadin challenge in the small intestine of celiac patients. Gastroenterology 1996;110:1368-78.

150. Lundin KEA, Sollid LM, Anthonsen D, et al. Heterogeneous reactivity patterns of HLA-DQ-restricted, small intestinal T-cell clones from patients with celiac disease. Gastroenterology 1997;112:752-9.

151. Moss SF, Attia L, Scholes JV, Walters JRF, Holt PR. Increased small intestinal apoptosis in celiac disease. Gut 1996;39:811-7.

152. Nakshabendi IM, Downie S, Russell RI, Rennie MJ. Increased rates of duodenal mucosal protein synthesis in vivo in patients with untreated celiac disease. Gut 1996;39:176-9.

153. Challacombe DN. Screening tests for celiac disease. Arch Dis Childhood 1995;73:3-7.

154. Sategna-Guidetti C, Grosso S, Bruno M, Bruna-Grosso S. Reliability of immunologic markers of celiac sprue in the assessment of mucosal recovery after gluten withdrawal. J Clin Gastroenterol 1996;23:101-4.

155. Cataldo F, Ventura A, Lazzari R, Balli F, Nassimbeni G, Marino V. Antiendomysium antibodies and celiac disease: solved and unsolved questions. An Italian multicentre study. Acta Paediatr 1995;84:1125-31.

156. Troncone R, and the SIGEP Working Group on Latent Celiac Disease. Latent celiac disease in Italy. Acta Paediatr 1995;84:1252-7.

157. Volta U, Molinaro N, De Franceschi L, Bianco-Bianchi F. Human umbilical cord as substrate for IgA antiendomysial antibodies allows large scale screening for celiac sprue. J Clin Gastroenterol 1996;23:18-20.

158. Catassi C, Ratsch IM, Fabiani E, et al. High prevalence of undiagnosed celiac disease in 5280 Italian students screened by antigliadin antibodies. Acta Pediatr 1995;84:672-6.

159. Hadjivassiliou M, Gibson A, Davies-Jones GAB, Lobo AJ,
Stephenson TJ, Milford-Ward A. Does cryptic gluten sensitivity play a part in neurological illness? Lancet 1996;347:369-71.

160. Gale L, Wimalaratna, Brotodiharjo A, Duggan JM. Down's syndrome is strongly associated with celiac disease. Gut 1997;40:492-6.

161. Catassi C, Fabiani E, Rätsch IM, et al. Is the sugar intestinal permeability test a reliable investigation for celiac disease screening? Gut 1997;40:215-7.

162. Smecuol E, Bai JC, Vazquez H, et al. Gastrointestinal permeability in celiac disease. Gastroenterology 1997;112:1129-36.

163. Iqbal ITH, Lewis KO, Gearty JC, Cooper BT. Small intestinal permeability to mannitol and lactulose in the three ethnic groups resident in West Birmingham. Gut 1996;39:199-203.

164. Teahon K, Somasundaram S, Smith T, Menzies I, Bjarnason I. Assessing the site of increased intestinal permeability in celiac and inflammatory bowel disease. Gut 1996;38:864-9.

165. Strocchi A, Corazza G, Furne J, et al. Measurements of the jejunal unstirred layer in normal subjects and patients with celiac disease. Am J Physiol 1996;270:G487-91.

166. Janatiunen EK, Pikkarainen PH, Kemppainen TA, et al. A comparison of diets with and without oats in adults with celiac disease. N Engl J Med 1995;333:1033-7.

167. Smecuol E, Gonzalez D, Mautalen C, et al. Longitudinal study on the effect of treatment on body composition and anthropometry of celiac disease patients. Am J Gastroenterol 1997;92:639-43.

168. Corazza GR, Andreani ML, Biagi F, Bonvicini F, Bernardi M, Gasbarrini G. Clinical, pathological, and antibody pattern of latent celiac disease: report of three adult cases. Am J Gastroenterol 1996;91:2203-7.

169. Picarelli A, Maiuri L, Mazzilli MC, et al. Gluten-sensitive disease with mild enteropathy. Gastroenterology 1996;111:608-16.

170. Barlow JM, Johnson CD, Stephens DH. Celiac disease: How common is jejunoileal fold pattern reversal found at small-bowel follow-through? AJR Am J Roentgenol 1996;166:575-7.

171. Fine KD, Meyer RL, Lee EL. The prevalence and causes of chronic diarrhea in patients with celiac sprue treated with a gluten-free diet. Gastroenterology 1997;112:1830-8.

172. Carroccio A, Iacono G, Lerro P, et al. Role of pancreatic impairment in growth recovery during gluten-free diet in childhood celiac disease. Gastroenterology 1997;112:1839-44.

173. O'Mahony S, Howdle PD, Losowsky MS. Review article: management of patients with non-responsive celiac disease. Aliment Pharmacol Ther 1996;10:671-80.

174. Ruan EA, Komorowski RA, Hogan WJ, Soergel KH Nongranulomatous chronic idiopathic enterocolitis: clinicopathologic profile and response to corticosteroids. Gastroenterology 1996;111:629-37.

175. Dickey W, McConnell JB. How many hospital visits does it take before celiac sprue is diagnosed? J Clin Gastroenterol 1996;23:21-3.

176. Collin P, Vilska S, Heinonen PK, Hällström O, Pikkarainen P. Infertility and celiac disease. Gut 1996;39:382-4.

177. Corazza GR, Di Sario A, Cecchetti L, et al. Bone mass and metabolism in patients with celiac disease. Gastroenterology 1995; 109:122-8

178. Mautalen C, Gonzalez D, Mazure R, et al. Effect of treatment on bone mass, mineral metabolism, and body composition in untreated celiac disease patients. Am J Gastroenterol 1997;92:313-8.

179. McFarlane XA, Bhalla AK, Reeves DE, Morgan LM, Robertson DA. Osteoporosis in treated adult celiac disease. Gut 1995;36:710-4

180. McFarlane XA, Bhalla AK, Robertson DAF. Effect of a gluten free diet on osteopenia in adults with newly diagnosed celiac disease. Gut 1996;39:180-4.

181. Bai JC, Gonzalez D, Mautalen C, et al. Long-term effect of gluten restriction on bone mineral density of patients with celiac disease. Aliment Pharmacol Ther 1997;11:157-64.

182. Collin P, Pukkala E, Reunala T. Malignancy and survival in dermatitis herpetiformis: a comparison with celiac disease. Gut 1996;38:528-30.

183. Murray A, Cuevas EC, Jones DB, Wright DH. Study of the immunohistochemistry and $\mathrm{T}$ cell clonality of enteropathy-associated T cell lymphoma. Am J Pathol 1995;146:509-19.

184. Besnard BP, Niot I, Bernard A, Carlier H. Cellular and molecular aspects of fat metabolism in the small intestine. Proc Nutr Soc 1996;55:19-37.

185. Amelsberg A, Schteingart CD, Stein J, et al. Intestinal absorption of sodium dodecyl sulfate in the rodent: evidence for paracellular absorption. Am J Physiol 1997;272:G498-506.

186. Poirier H, Degrace P, Niot I, Bernard A, Besnard P. Localization and 
regulation of the putative membrane fatty acid transporter (FAT) in the small intestine. Comparison with fatty acid binding proteins (FABP). Eur J Biochem 1996;238:368-73.

187. Hodson ME, Ponder JW, Cistola DP. The NMR solution structure of intestinal fatty acid binding protein complexed with palmitate: application of a novel distance geometry algorithm. J Mol Biol 1996;264:585-602.

188. Hsu K-T, Storch J. Fatty acid transfer from liver and intestinal fatty acid binding proteins to membranes occurs by different mechanisms. J Biol Chem 1996;271:13317-23.

189. Cistola DP, Kim K, Rogl H, Frieden D. Fatty acid interactions with a helix-less variant of intestinal fatty acid binding protein. Biochem 1996;35:7559-65.

190. Kim K, Cistola DP, Frieden C. Intestinal fatty acid binding protein: the structure and stability of a helix-less variant. Biochem 1996;35:7553-8.

191. Richieri GV, Ogata RT, Kleinfeld AM. Kinetics of fatty acid interactions with fatty acid binding proteins from adipocyte, heart and intestine. J Biol Chem 1996;271:11281-300.

192. Baier LJ, Bogardus C, Sacchettini JC. A polymorphism in the human intestinal fatty acid binding protein alters fatty acid transport across Caco-2 cells. J Biol Chem 1996;271:10892-6.

193. Prows DR, Murphy EJ, Moncecchi D, Schroeder F. Intestinal fatty acid binding protein expression stimulates fibroblast fatty acid esterification. Chem Phys Lipids 1996;84:47-56.

194. Fontaine RN, Gossett RE, Schroeder F, Otoole BA, Doetschman T. Liver and intestinal fatty acid binding proteins in control and TGF beta 1 gene targeted deficient mice. Mol Cell Biochem 1996;159:149-53.

195. Murthy S, Mathur SN, Bishop WP, Field FJ. Inhibition of apolipoprotein B secretion by IL-6 is mediated by EGF or an EGF-like molecule in Caco-2 cells. J Lipid Res 1997;38:206-16.

196. Aldini R, Roda A, Montagnani M, Cerre C, Pellicciari R, Roda E. Relationship between structure and intestinal absorption of bile acids with a steroid or side-chain modification. Steroids 1996;61:590-7.

197. Kramer W, Girbig F, Gutjahr U, Kowalewski S. Radiationinactivation analysis of the $\mathrm{Na}^{+}$/bile acid cotransport system from rabbit ileum. Biochem J 1995;306:241-6.

198. Shneider BL, Dawson PA, Christie DM, Hardikar W, Wong MH, Suchy FJ. Cloning and molecular characterization of the ontogeny of a rat ileal sodium-dependent bile acid transporter. J Clin Invest 1995;95:745-54.

199. Stengelin S, Apel S, Becker W, et al. The rabbit ileal lipid-binding protein. Gene cloning and functional expression of the recombinant protein. Eur J Biochem 1996;239:887-96.

200. Tsuchiya T, Kalogeris TJ, Tso P. Ileal transposition into the upper jejunum affects lipid and bile salt absorption in rats. Am J Physiol 1996;271:G581-91.

201. Chazouilléres O, Marteau P, Haniche M, Jian R, Poupon R. Ileal absorption of bile acids in patients with chronic cholestasis. Dig Dis Sci 1996;41:2417-22.

202. Hashimoto S, Igimi H, Uchida K, Satoh T, Benno Y, Takeuchi N. Effects of $\beta$-lactam antibiotics on intestinal microflora and bile acid metabolism in rats. Lipids 1996;31:601-9.

203. Engle MJ, Grove ML, Becich MJ, Mahmood A, Alpers DH. Appearance of surfactant-like particles in apical medium of Caco-2 cells may occur via tight junctions. Am J Physiol 1995;268:C1401-13.

204. Shamir R, Johnson WJ, Zolfaghari R, Lee HS, Fisher EA. Role of bile salt-dependent cholesteryl ester hydrolase in the uptake of micellar cholesterol by intestinal cells. Biochemistry 1995;34:5351-8.

205. Carr TP, Gallaher DD, Yang C-H, Hassel CA. Increased intestinal contents viscosity reduces cholesterol absorption efficiency in hamsters fed hydroxypropyl methylcellulose. J Nutr 1996;126:1463-9.

206. Overturf ML, Smith SA, Gotto AM Jr, et al. Dietary cholesterol absorption, and sterol and bile acid excretion in hypercholesterolemia-resistant while rabbits. J Lipid Res 1990;31:2019-27.

207. Pakarinen M, Miettinen TA, Lauronen J, et al. Adaptation of cholesterol absorption after proximal resection of porcine small intestine. J Lipid Res 1996;37:1766-75.

208. Nilsson A, Becker W. Uptake and interconversion of plasma unesterified $n-3$ polyunsaturated fatty acids by the GI tract of rats. Am J Physiol 1995;268:G732-8.

209. Melin T, Qi C, Nilsson A. Bile but not chyle lipoprotein is an important source of arachidonic acid for the rat small intestine. Prostaglandins Leukot Essent Fatty Acids 1996;55:337-43.

210. Field FJ, Born E, Mathur SN. Effect of micellar $\beta$-sitosterol on cholesterol metabolism in Caco-2 cells. J Lipid Res 1997;38:348-60.

211. Gugger ET, Erdman JW Jr. Intracellular $\beta$-carotene transport in bovine liver and intestine is not mediated by cytosolic proteins. J Nutr 1996;126:1470-4.

212. Duszka C, Grolier P, Azim E-M, Alexandre-Gouabau M-C, Borel P, Azais-Braesco V. Rat intestinal beta-carotene dioxygenase activity is located primarily in the cytosol of mature jejunal enterocyte. J Nutr 1996;126:2550-6.

213. Lin HC, Zhao X-T, Wang L. Fat absorption is not complete by midgut but is dependent on load of fat. Am J Physiol 1996;271:G62-7.

214. Nishimura M, Seishima M, Ohashi H, Noma A. Effects of lipid administration on lymphatic apolipoprotein A-IV and B output and synthesis. Am J Physiol 1996;271:G322-9.

215. Gonzalez-Vallina R, Wang H, Zhan R, et al. Lipoprotein and apolipoprotein secretion by a newborn piglet intestinal cell line (IPEC-1). Am J Physiol 1996;271:G249-59.

216. Sakata Y, Fujimoto K, Ogata S-I, et al. Postabsorptive factors are important for satiation in rats after a lipid meal. Am J Physiol 1996;271:G438-42.

217. Wang H, Zhan R, Hunter F, Du J, Black D. Effect of acute feeding of diets of varying fatty acid composition on intestinal apolipoprotein expression in the newborn swine. Pediatr Res 1996;39:1078-84.

218. Kalogeris TJ, Monroe F, Demichele SJ, Tso P. Intestinal synthesis and lymphatic secretion of apolipoprotein A-IV vary with chain length of intestinally infused fatty acids in rats. J Nutr 1996;126:2720-9.

219. Ginsberg GS, Ozer J, Karathanasis SK. Intestinal apolipoprotein AI gene transcription is regulated by multiple distinct DNA elements and is synergistically activated by the orphan nuclear receptor, hepatocyte nuclear factor 4. J Clin Invest 1995;96:528-38.

220. Fong LG, Fujishima SE, Komaromy MC, Pak YK, Ellsworth JL, Cooper AD. Location and regulation of low-density lipoprotein receptors in intestinal epithelium. Am J Physiol 1995;269:G60-72.

221. Funahashi T, Giannoni F, DePaoli AM, Skarosi SF, Davidson NO. Tissue-specific, developmental and nutritional regulation of the gene encoding the catalytic subunit of the rat apolipoprotein B mRNA editing enzyme: functional role in the modulation of apo B mRNA editing. J Lipid Res 1995;36:414-28.

222. Pidlich J, Renner F, Ellinger A, Huttinger M, Pavelka M, Gangl A. Effect of pluronic L-81 on intestinal lipoprotein secretion in the rat. Dig Dis Sci 1996;41:1445-51.

223. Soued M, Mansbach CM II. Chylomicron remnant uptake by enterocytes is receptor dependent. Am J Physiol 1996;270:G203-12.

224. Levy E. The genetic basis of primary disorders of intestinal fat transport. Clin Invest Med 1996;195:317-24.

225. Kalogeris TJ, Gray L, Yeh YY, Tso P. Triacylglycerol and cholesterol transport during absorption of glycerol trioleate vs glycerol trielaidate. Am J Physiol 1996;270:G268-76.

226. Young SG, Cham CM, Pitas RE, et al. A genetic model for absent chylomicrone formation: mice producing apolipoprotein $\mathrm{B}$ in the liver, but not in the intestine. J Clin Invest 1995;96:2932-46. 


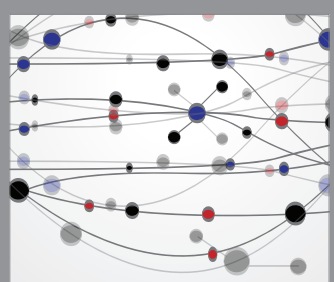

The Scientific World Journal
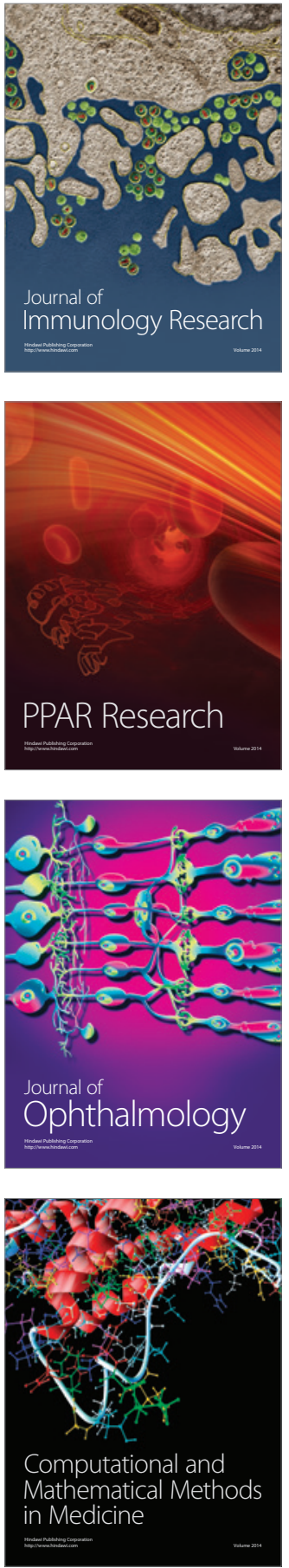

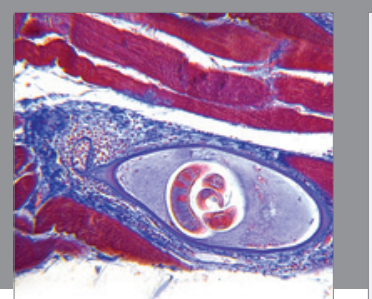

Gastroenterology Research and Practice

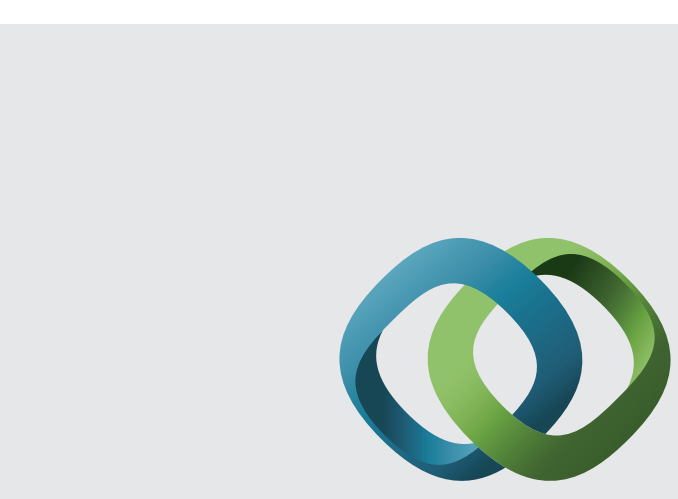

\section{Hindawi}

Submit your manuscripts at

http://www.hindawi.com
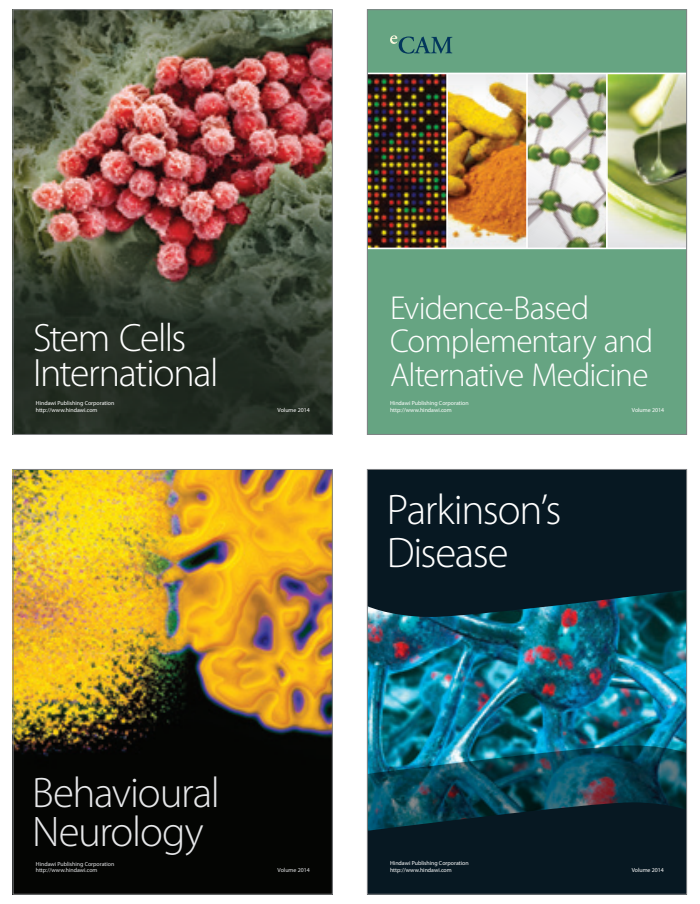
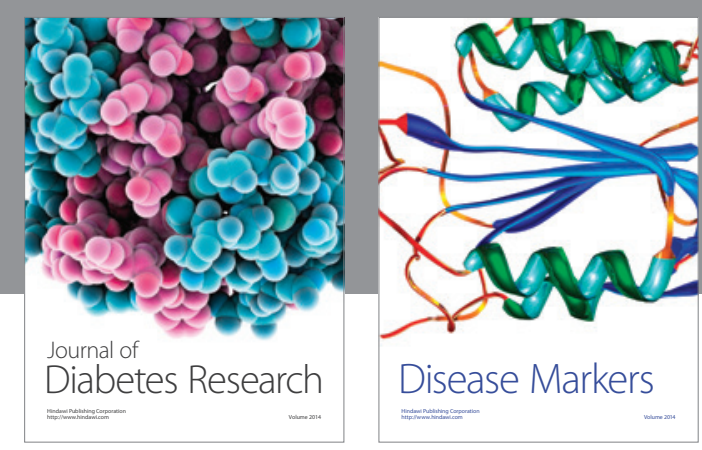

Disease Markers
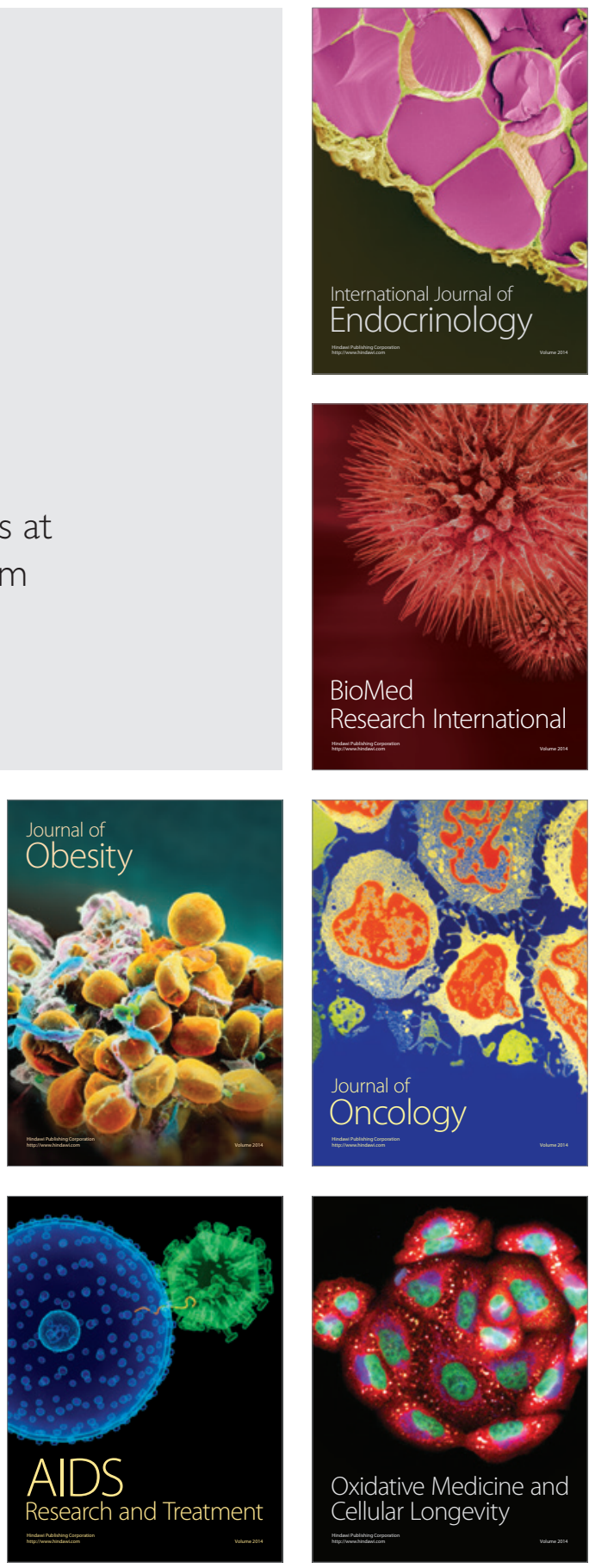